\title{
Violent ends
}

\section{Introduction: a biographical approach to life, death and deposition}

The lives of the people who were buried or interred in the bog used to be defined by how they died. While that is of interest here, developments in archaeological techniques now enable us to examine much more about the lives they lived before that point, encompassing both fleshed and skeletal remains (e.g. Pestka et al. 2010). In particular, light stable isotope analysis has enabled us to examine their origin and mobility or (as we shall see) the distance that some of their clothing or accoutrements might have travelled. Casting the net of bog bodies wider to include skeletonised remains from places such as Sweden has allowed specialists to examine aspects of welfare and disease, which sheds a rather different light on those who ended up in the bog. Non-invasive computed tomography (CT) scanning can refine the litany of ante- and peri-mortem trauma, while forensic knowledge has enabled us to both observe subtle injuries we once missed and to write off some of the apparent 'overkill' we see as the result of compression in the bog or post-mortem damage during discovery. Enhanced scanning electron microscopy (SEM) has revealed details of hairstyles and the preparation of the body before death, while archaeobotanical analysis has given us further evidence of 'last meals', as well as the depositional environment in which they were found. Refined accelerator mass spectrometry (AMS) dating has helped pinpoint a tighter window of death and deposition, despite concerns over its validity (discussed in Chapter 4). Despite the illusion of corporeal stasis, no bog body has so far yielded enough preserved ancient DNA to yield a positive result. While this data would of course be of intrinsic interest, the grand narratives it tends to produce will not necessarily illuminate the character of the life lived by that individual and the death experienced by them, and it is this biographical lens that I will adopt here to understand the circumstances behind their fate and deposition in the bog.

Inevitably the pattern of research is uneven; some bodies have attracted significant research funding and attention (Nordström 2016), yet the most iconic remains are ironically limited in terms of the invasive or destructive sampling that might be permitted due to both ethical and aesthetic restrictions: no one is 
going to prise a tooth out of Tolland Man's mouth (Nielsen pers. comm.)! It is in some of the newest and fragmentary, desiccated, archival or poorly preserved examples that such research techniques are being strategically deployed. Many bog body publications offer specialist reports on a narrow avenue of research, inevitably divorcing details of disease or injury from origin, last meals or clothing, or the exact locale and character of deposit. Yet these contextual associations help us build up a picture of how a life was lived and thus how it may have related to the death that was experienced. Here, using this guiding framework of the biography, the chapter will critically reflect on contrastive case studies to consider the possibility of accidental death, interpersonal violence, murder or manslaughter, suicide, formal burial and so-called 'bad deaths' that might require non-normative treatment or furtive interment. It will then move to the examples that suggest planned, premeditated violence that often has a highly performative, 'ritualised' character, appearing socially sanctioned and publically executed. The chapter will then evaluate the competing explanations of bog bodies, favouring a multiplicity of interpretations (see Hutton 2004b; Giles 2009; Joy 2009) argued on a caseby-case basis, setting these in context with wider evidence for violence in the Iron Age and early Roman era.

\section{The many different ways to die}

\section{Accidental death, suicide and murder}

The bog undoubtedly wrought its mercurial and merciless power over a number of victims who appear to have died accidentally. The skeleton and skin of an 'upright man' from Asby Moor in Lincolnshire found in 1724 (Briggs 1995: 211) and a man found with a 'hazel walking stick' on Seascale Moss in Cumbria (Briggs 1995: 209) both sound like accidents, where walkers came to their death while trying to cross a treacherous area (recalling the end of the villainous Stapleton in Conan Doyle's The Hound of the Baskervilles). We know this to be the fate of Nat Bell and Radcliffe, sodden with drink and drowning or dying of exposure on Lindow Moss; Red Christian, who went missing in similar circumstances in Denmark but was never found; the couples from Hautes Fagnes in Belguim and Hope in the Peak District; the children from Lewis and the elderly man from Roundstone bog in Ireland (see Chapters 2 and 4). At Gunnister on Shetland, a bog body was found fully clothed (coat, jacket, breeches, gloves, cap and stockings) with an extraordinary array of objects: wooden pail, knife, horn spoon, quill, horn 'ink pot' and purse full of coins (Cowie et al. 2011) - there is no sense of foul play or robbery and it is likely he died while crossing to complete some scribal task in a remote area (see Figure 6.1a). Among the archaeological bog bodies, the Vehne bog body from Germany, splayed out, clutching a tussock of peat in his hand, and also the Tumbeagh bog body, have been seen as unfortunate individuals who strayed from the trackway or failed to make the crossing over the firmer tussocks of the bog (see Chapter 4). To 


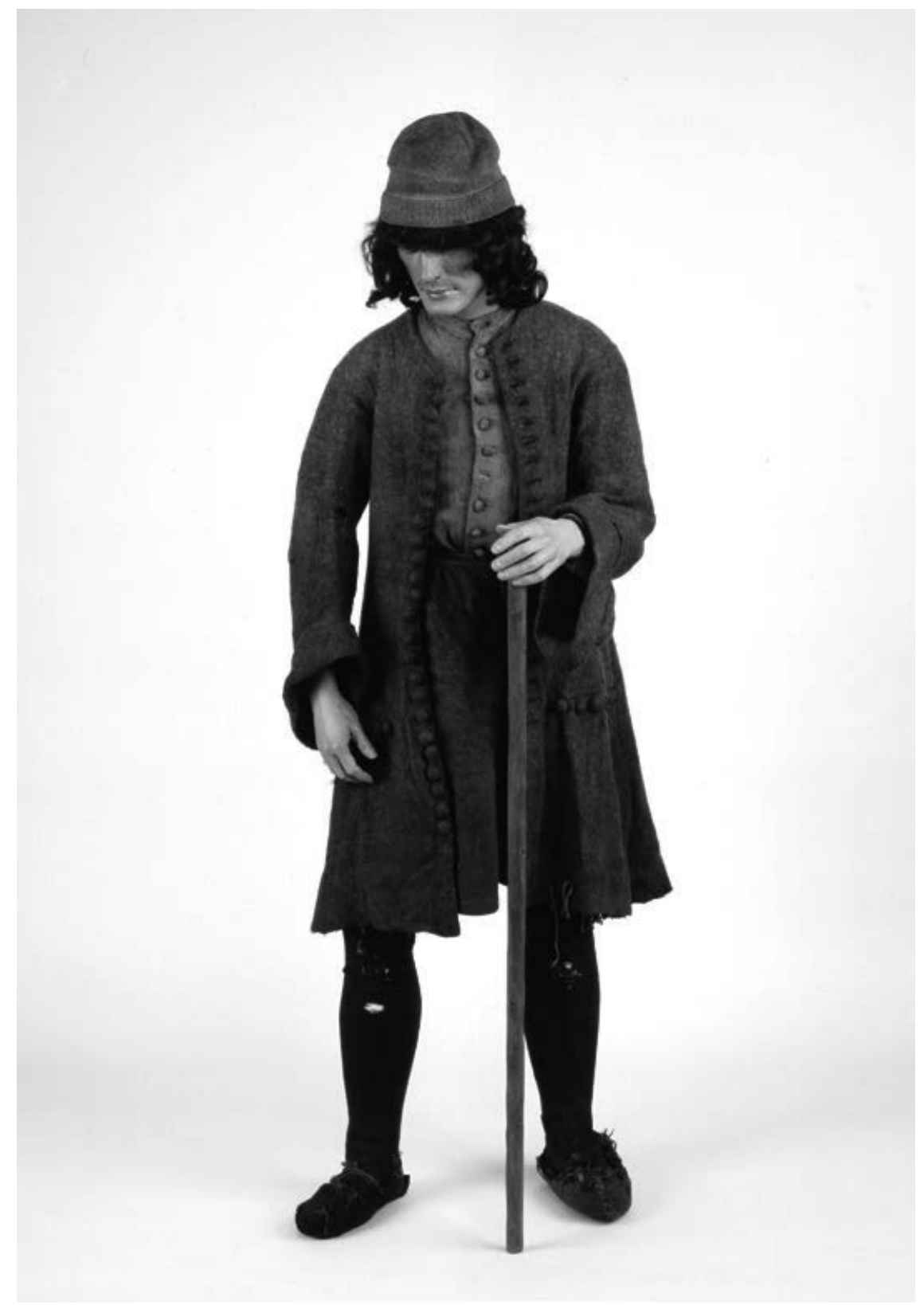

6. I a The Gunnister bog body clothing. All rights reserved and permission to use the figure must be obtained from the copyright holder. 


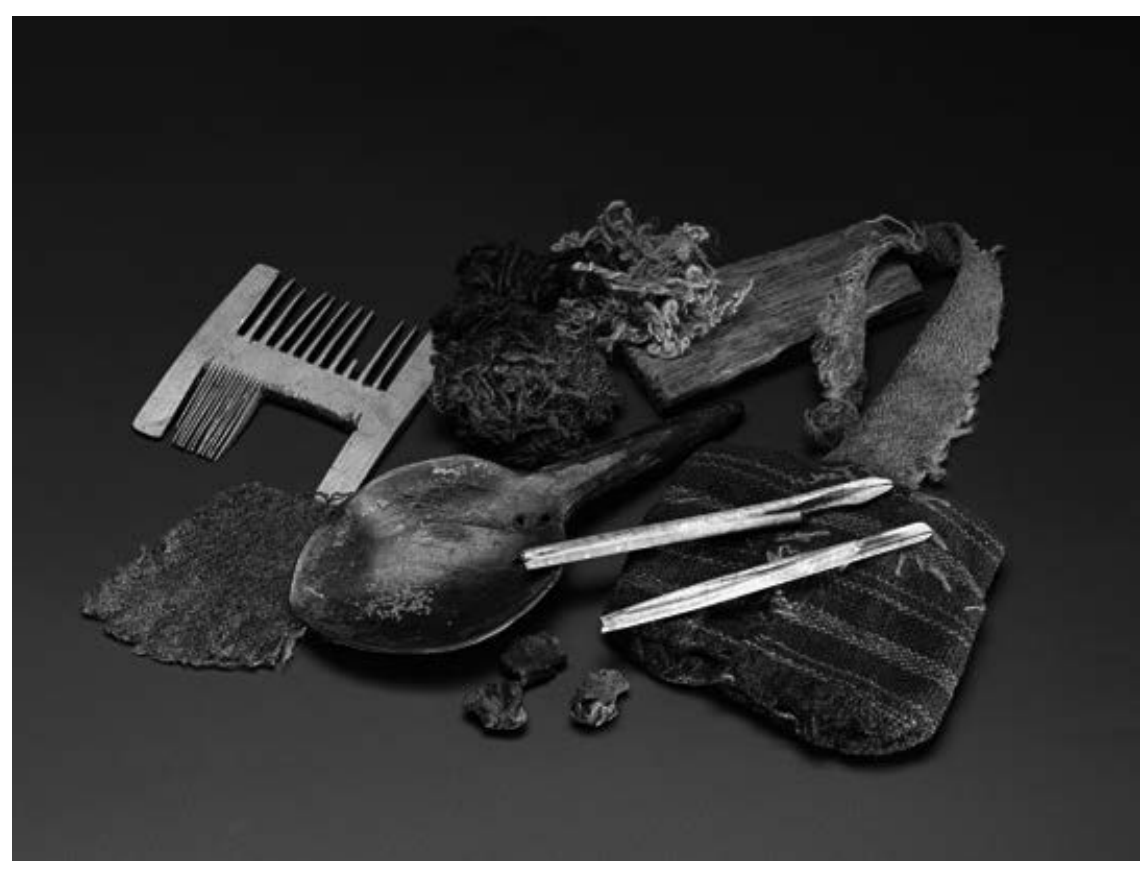

6. I b Arnish Moor man's possessions. All rights reserved and permission to use the figure must be obtained from the copyright holder.

this of course, we can add those killed in bog bursts, particularly in Ireland. The bog was not the only dangerous water body: death by misadventure is seen as a laudable explanation for at least some of the prehistoric human remains recovered from the River Thames (Carr and Knüsel 1997; Edwards et al. 2010).

As with most of those major rivers, we also know of several suicides: poor Mary Daniell, leaving her kin and kine on Ashton Moss; Berrybrush in Scotland; Ardee bog in Ireland; and the folkloric legends of noble women in Estonia, taking their own lives during conflict (see Chapters 2 and 4). A twisted birch rope was found alongside the young man from the Stuart Dynasty era, found at Clayton Hill in Scotland, which may also indicate a suicide (or improvised hanging): the corpse was covered over with heavy slabs or stones (Cowie et al. 2011). At Ballygudden, in Ireland, the discovery of a woman in the bog in 1831 was followed by the swift realisation she was accompanied by an infant with a belt around its neck, fastened tight by a small buckle (Turner and Briggs 1986: 156). In his original account, Briggs argues this might be a kind of primitive papoose or else a failed rescue attempt by a mother trying to 'lasoo' the child, 'only to find herself at victim of the mire' (Turner and Briggs 1986: 156). By 1995, when Briggs was clearly frustrated by the immediate leap to interpret bog bodies as 'ritual sacrifices', this latter accidental death theory became his only interpretation. The more uncomfortable possibility 
of infanticide that he proposes in 1986 actually seems more likely: there are many reasons why a mother might despair and take her infant's life, not least during periods of conflict or dearth. Whether she then drowned herself or was punished by her community is unclear. Sometimes the boundary between accident and suicide might be deliberately obfuscated, to preserve hope for the soul of the dead, as was suggest for William Walker on Ashton Moss (see Chapter 4). Tumbeagh has also been posited as the burial of a suicide victim, excised from sanctified ground due to dying at her own hand.

We know that some people fled on to the moss trying to escape certain death: the Solway Moss 'armed figure' on horseback (Lyell 1838), and the Summersdale, Slamannon, Alford and Kilsyth bog bodies from Scotland (Cowie et al. 2011) are likely to all represent post-medieval conflict victims, fleeing a pursuer. In Ireland and the British Isles, bog bodies were readily attributed to Anglo-Scots or AngloIrish conflict as well as clan violence and religious persecution (such as the execution of Covenanters, see Cowie et al. 2011). Yet where tartan cloth, saddlery and arms were found in association with such remains (e.g. Torr na Cabar, see Cowie et al. 2011: 28), this seems a reasonable interpretation. The downed Luftwaffe airman from South Zealand (Lynnerup 2015) merely represents the last in such war-related victims who may have sought to escape, find refuge, or vainly hope for a soft-landing in the bog.

A certain number of bog bodies, particularly those from the post-medieval era, can be attributed through rumour, report or evidence to murder. The female bog body from Evie, Orkney was found in 1864 covered in two petticoats: one wrapped around the lower part of the body and the other wrapped and stitched in place around the trunk and head with trimming (Cowie et al. 2011:21-2). The original report recorded that the posterior part of the brain seemed much 'redder' than the rest and the preserved brain tissue appeared to be mixed with 'a considerable quantity of blood' (Cowie et al. 2011: 21-2), but if this was a blow from behind, the body had been afforded the equivalent of a laying out and improvised shrouding for interment. The woman herself seems to date to the 1600 s, and as noted in Chapter 4, she was anecdotally related to the apparent murder of one Mary Linklater in 1600 by the 'Two Rendall witches'. Whether the Evie bog body was their victim or not, the notion that femicide might be instigated by women from their own community is one we should bear in mind.

The young man from Arnish Moor (Lewis) found in 1965, was fully clothed with scholar's bag and quills, spoon, comb and much-patched clothing (Figure 6.1b). His distinctive gait and blunt-trauma head wound has plausibly been linked to a manslaughter carried out in the early eighteenth century, according to the Scottish Daily Mail (Cowie pers. comm.). Two school friends from Stornoway had been on a bird-nesting expedition when they quarrelled and one young man fatally hit his friend over the head with a stone, burying him hastily in the bog. After running away to sea for a few years, the murderer was recognised upon his return to Stornoway; he was arrested, confessed and hanged for the crime but the body took two hundred years to re-emerge. Meanwhile, a corpse from Quintfall 
bog found in 1920 was also found fully dressed in clothes that placed him in the late seventeenth century. Again, a blow to the head seems to be the cause of his demise but this was no simple mugging: a purse filled with nineteen 'bawbees' dating to the 1690 s showed that he had not been robbed. The apparently naked male bog body with fulsome moustache buried at Walls on Hoy had his wrists firmly bound with what was described as 'straw', yet this was tight enough to have firmly indented itself into the flesh of the wrists (cited in Cowie et al. 2011: 24). No trace of wound was observed, yet it sounds as if he had been stripped, bound and dispatched in a deliberate manner: possibly drowned. The rough justice that may be exhibited here was certainly meted out to the licentious tacksman from Lewis, whether or not it was his body that was recovered at Garynahine in Lewis (Cowie et al. 2011: 25). In Sweden, the medieval case of Bocksten Man found 'driven through' by wooden stakes was interpreted as a murder, though the 'pinning' of the body might have been post-mortem and related to the concept of the Weerdinger or restless corpse (van der Sanden 1996: 85). As discussed in Chapter 2, the fear that the Rørbæk body was the work of notorious local murderer Ni-Kristian shows that by the historic period, the increased marginalisation of this landscape made it the perfect place to hide such remains (as with the notorious 'Moors Murders' in Britain). Whether it was an example of premeditated murder or a 'crime of passion', the Little Moss 'fruit knife' victim from Ashton proves that by the late 1800s, the semi-drained bog or mire was a secluded place where people might be lured for liaison but also hidden from view. We certainly know that Maria Reyn-Bardt was - by her husband's own admission - murdered, burned and buried in the bog in the 1960s, and the hope that 'Moora' (the female bog body from Uchter Moor) was the still-missing Elke Kerl, lost on her way back from a dance hall in 1969 (see Chapter 2), as well as the remaining 'Disappeared' from Ireland, warn us that recent murders still await discovery.

What is notable in the above examples is that most of them are interred fully clothed, often with personal possessions. Rarely does this seem to be an anonymous mugging on the moor; their demise is often the result of a single if savage blow, or death by drowning or hanging. Do we have prehistoric examples of murder? In the report on the Hooghalen bog body from the Netherlands, it was noted that the 'back of his head had been smashed' (cited in van der Sanden 1996: 64). The injury from behind and deposition of the body on its face - prone in the bog - sound more like a murder or manslaughter, yet the 'Suebian' knot hairstyle and composite skin cape confirms this 'paper' bog body was late Iron Age or early Roman in date, analogous to Osterby Man from Germany. From the Fenlands, a female bog skeleton from Southery nicknamed 'Nancy' was found face downwards again, with one hand in front of the face, the other stretched out; she was found with jet beds and a bronze awl (van der Sanden 1996: 75 and 95). Torresta Man, a bog skeleton from Sweden dating to the Roman Iron Age, had led a hard life, recovering from some blunt-force trauma to the skull and healed 'butterfly' fracture of his right fibula, with some deformation of the metatarsals suggesting he would have walked thereafter with a limp (Fredengren and Löfqvist 2015). While these injuries might 
have been sustained in working life, he had certainly died violently: a thin sharpforce cut to the right collarbone may have caused haemorrhaging from the throat while a sharp-force wound just above the right knee and several cuts behind the left knee may have been designed to immobilise him, causing him to fall upon his front. He had peri-mortem sharp-force cuts to both the right temporal and left occipital bone, suggesting four short, savage blows to the back of the skull when he lay prone. Finally, there was a deep cut to the lower stomach (biting into the ilium) with a follow-up deeper stabbing that sliced off the top of the coxae (Fredengren and Löfqvist 2015), suggesting deep penetrating wounds to his lower torso from behind. Additionally, he was found close to a rope, suggesting possible restraint or even attempted hanging that was then 'finished off' with bloodshed. Multiple assailants may have been involved in what might have been a more staged execution or orchestrated killing - what Fredengren and Löfqvist (2015: 140) call 'networked violence', meted out to an individual already caught up in previous incidents of conflict. The evidence for old trauma and decreased mobility suggests to them a pathway of neglect, stigmatisation and eventual emasculation, though of course this could also be a matter of revenge.

In the era defined by the massive weapons deposits in Denmark, we have a number of multiple bog burials that might suggest the massacre of a family group: two men and five children (including two infants) at Hundstrup Mose, dating to the second half of the first millennium BC (van der Sanden 1996: 104), and Rislev, where two women and a child were buried in a mixed deposit of animal bones, covered by branches (van der Sanden 1996: 104), dating to the fourth or fifth century AD. Such rare multiple burials probably represent larger-scale killings, but in the absence of sharp-force wounds we should also be open to the possibility of death from disease - perhaps the bog's renowned medicinal power was being drawn upon to contain and curtail an epidemic.

The Weerdinge 'couple' (c.160 BC-AD 220) from the Netherlands have been positively identified as male, found together on Bourtangermoor, one lying on the arm of the other; this was the moss noted in Chapter 4 for the evidence of trackways running out into the bog, where cutting not just for peat but iron ore may have precipitated a bog burst (Casparie 1986). One of the men met a violent end, with a severe wound to the left hand side of his chest, through which his intestines had spilled out, prior to burial in the bog (van der Sanden 1996). This has been linked by some authors to texts by both Diodorus Siculus and Strabo on Gaul and Britain, which suggest that that some tribes practised divination by ritualised execution: reading a man's entrails (Oldfather 1933: V.31.3-4) or his death struggles (Strabo Geographia IV, 4.5 and VII, 2.3 cited in Aldhouse-Green 2002: 83). Given their gender, there is the ugly possibility that this was the deliberate killing of a same-sex couple, visually fulfilling the prejudicial reading of Tacitus by the Nazis (Taylor 2008). Yet it is just as likely that that these men were comrades who died either in a violent altercation or were taken as high-status prisoners: 'spilling your guts' can be a metaphor for betrayal - perhaps this was the chosen fate for an enemy captive. 
At the opposite end of this spectrum of violence lie the rare examples of total destruction that speak not just of a need to remove any trace of personhood but something more pathologically inclined. The Lyngby bog skeleton from Everöd, Sweden, for example, dating to the late Bronze Age, has recently been interpreted by Bergerbrant and Molnar (2019) as a piece of murderous obliteration. Three circular fractures to the head (perhaps caused by a spear shaft?) and a massive blow to the skull, stab wounds to the abdomen and hip (from a dagger or knife), deep 'chopping' blows to the mandible (possibly caused by an axe) and over seven hundred smaller cut marks across all skeletal elements (including the interior of the cranium) suggest multiple fatal wounds followed by dismemberment and complete defleshing of the body. Bergerbrant and Molnar (2019) consider this not to be ritualised killing but rather, the obsessive and pathological 'work' of a late Bronze Age murderer.

\section{Burial and mortuary rites: curating the dead?}

In contrast, a number of bog bodies - both complete and fragmentary remains probably represent normative mortuary rites for the time. For example, Turner (1995b) records a number of both fragmentary skulls, mandibles and body parts that appear to date mainly from the Bronze Age to Iron Age fenlands (Burwell Fen, Fengate Power Station, Isleham Fen). These remains may once have been formal burials or excarnated remains but unfortunately it is their crania that were selectively curated for the Sedgewick Museum at Cambridge. Some of these may have been interred in ground that was only seasonally wet, akin to the Eton Rowing lake burials dating from c.1300-200 BC, buried on sand-bank islands and deliberately 'weighted' down due to the increased flooding (Dennison 2000). Formal log coffin burials dating from early Bronze Age Scotland are discussed in Cowie et al. (2011: 6-7). At Methwold, no less than ten 'bog bodies' were found either with bronze awls or flint scrapers, representing formal burials from the Neolithic to the early Bronze Age (Briggs 1995: 212-14). Balgone 1 and 2, found with animal bones and a jet belt slider (Cowie et al. 2011: 29), and Soham Fen from the Cambridgeshire fens, interred with early Bronze Age jet beads and spacer plates from a necklace (Briggs 1995: 207), both appear to be plausible burials with grave goods. At West Tofts in Britain, the discovery of thirty blue glass or faience beds, a 'gold funnel' and 'face carved in Lancashire black coal' with human remains contained in a coffin, best resemble an early Bronze Age coffin or log boat burial (van der Sanden 1996: 95). The Prestatyn infant from Wales, buried in the later Iron Age/early Roman era, seems to have been interred at the edge of a tree growing right on the fringe of a bog, the burial further marked by a small fenced, oval enclosure (van der Sanden 1996 : fig. 33). It is the context and association between mother and child that makes the Derrymaquirk bog body from Ireland (a woman of $c$. twenty-five years of age, found with the remains of a $c$. two-year-old) appear a formal interment. An oval grave, filled with branches and twigs also contained 
a large block of wood like a headboard at one end and an oval, flat stone placed over the pelvic area at the other (van der Sanden 1996: 96). She was buried with an antler tine (hollowed out for a handle or haft?) and faunal remains (sheep/goat and dog), dating to the early Iron Age (593-346 cal BC at 66.3 per cent probability). While there are no obvious causes of death, the association of mother and child might suggest a mysterious double death from infection or disease. The symbolic weighting down of the pelvic area could indicate some concern with her unfinished life and procreative power.

In Denmark too, we see a number of plausible burials: the Korselitse remains from Denmark were found with seven glass beads (four circular, three petal shaped) and a bronze brooch, which led Ravn (2011) to conclude this was a burial in keeping with contemporary funerary traditions. Borromose Woman, found in 1947, was wrapped around the legs with two woollen blankets, a shawl and around her neck a leather thong in which were strung a bronze disc and an amber bead (Asingh and Lynnerup 2007: 298). She was associated with bones from an infant but it is unclear if this was effectively a double burial or if they were token bones, 'kept relics' from a dead child (Fischer (2012: 128) interprets this as a male burial). Damendorf Girl was associated with a leather container made from two types of hide, decorated with horsehair (Fischer 2012: 95), whereas another body from the same bog but a different locale, Damendorf Man, had a pair of shoes and a leather belt laid alongside him (Asingh and Lynnerup 2007: 304).The Hunteberg Men another double male burial - seem respectfully buried, wrapped up in their cloaks that were tucked around their feet (van der Sanden 1996: 123). These remains may suggest a period when the bog was used for formal burial, though again a sudden or multiple death might occasion the choice of this odd locale. One of the very rare child bog bodies comes from Röst, in Germany, where a young girl was laid gently in a pit, in the 'pea on a fork' posture that every parent would recognise as one of relaxed sleep. Aged only two to three years, she was covered with a blanket and then overlaid by turves (van der Sanden 1996: 82), in what seems to be a formal burial - perhaps after an unexplained 'cot' death or illness. Dröbnitz Girl from Poland, dating to the early Iron Age (eighth to fifth century BC), was found with a decorated wooden comb, which had been tied to her skin cape with a woollen thread (van der Sanden 1996: 95). Finally, the timber arrangement at Bunsoh in Germany suggests a formal mortuary structure, in which further twigs and stakes were used to cover and possibly pin down the corpse (van der Sanden 1996: 100). Though rare, the bog was clearly the place chosen to inter some individuals.

Writing about Huldremose Woman, Liversage (1984) presciently proposed that interment in the bog was done deliberately in contemporary bog pits or pools, cognisant of its preservative properties. Briggs (1995: 170) scoffs at the suggestion, arguing that 'this almost assumes the body to have been buried by people who anticipated body preservation'. The communities who interred their bog butter in Scottish and Irish bogs certainly did! So too, thought Gibson, who wrote of the well-preserved coffin burial at Mownog found in 1684: 'they who placed this coffin here might have regard to the perpetual preservation of it, seeing we find, by 
daily examples of threes found in turbaries, that such bituminous earth preserves beyond all others' (cited in Camden 1722: 775). One suite of burials from the late Bronze Age demonstrates that the bog might be used temporarily and strategically within wider mortuary rites that are much more complex than we suppose. At Cladh Hallan on South Uist, the burial of a skeletonised male individual seems to have been laid down in the machair around 1440-1260 BC, some time before a female burial, and after a century or two, both were overlain by three sunkenfloored roundhouses (Parker Pearson et al. 2005; Parker Pearson et al. 2007). The male 'burial' was, however, revealed to be a composite of three mummified individuals: the post-cranial skeleton of one male, the cranium and cervical vertebrae of another (an older man, showing articulation of the remains, osteoarthritis and lack of dentition in the maxilla), and the mandible of a well-dentured final individual (Parker Pearson 2016: 8) (see Figure 6.2). Analysis from the aDNA from the 'female' skeleton also revealed that it too was a composite: with the mandible, right arm and femur all derived from separate individuals - mainly a male skull and female torso, with the male fragments pre-dating the female components by around 70-205 years (Parker Pearson et al. 2013: 11). Fascinatingly, 'his' two upper lateral incisors had been removed from his jaw sometime after death and placed in 'her' hands. Even her skeleton showed manipulation and selective removal: she lacked the distal end of her left femur, patella and proximal ends of her left fibula and tibia; in other words, much of her left knee appeared to have been broken off. There was no sign of disturbance from above and the fractures were identified as 'dry': this had happened post-mortem, but while the collagen was still flexible but prior to interment. The distal end of her right radius was also missing postmortem. The missing body parts were found interred within a pit outside of the same roundhouse, mixed with red peat ash (note the use of local peat for fuel) and domestic debris. The snapped-off 'knee' may have been kept as a relic for some time before deposition close to rest of the corpse.

The excavators considered that the large articulated body parts had been kept above ground, tightly wrapped and in a protective environment: warm and dry enough to inhibit soft tissue decay - a 'mummy house' in effect - before the breaking and taking of an articulated 'joint' from an already desiccated corpse (Parker Pearson et al. 2007; Hanna et al. 2012). The quote regarding the food-preservation technique of Hebridean 'skewing' mentioned by Anderson in 1879 (see Chapter 3) would seem to fit the bill well, or else suspension in the rafters of a later prehistoric roundhouse. The analysts proposed that what might be at work in such osteological bricolage was the making of a composite ancestral 'body' that spanned time (Hanna et al. 2012: 2779). Yet all of the remains also showed the loss of calcium mineral content in the outermost layers of the bone; interpreted by the team as the result of temporary immersion in an acidic environment before this skewing process, most likely the acid peat bogs found nearby (Parker Pearson et al. 2005: 542). The remains were also stained a distinctive peat-brown colour indicative of the 'tanning' effect of the bog on both tissue and bone (Parker Pearson 2016). Once recognised, and with a new methodological toolkit to recognise this phenomenon, 


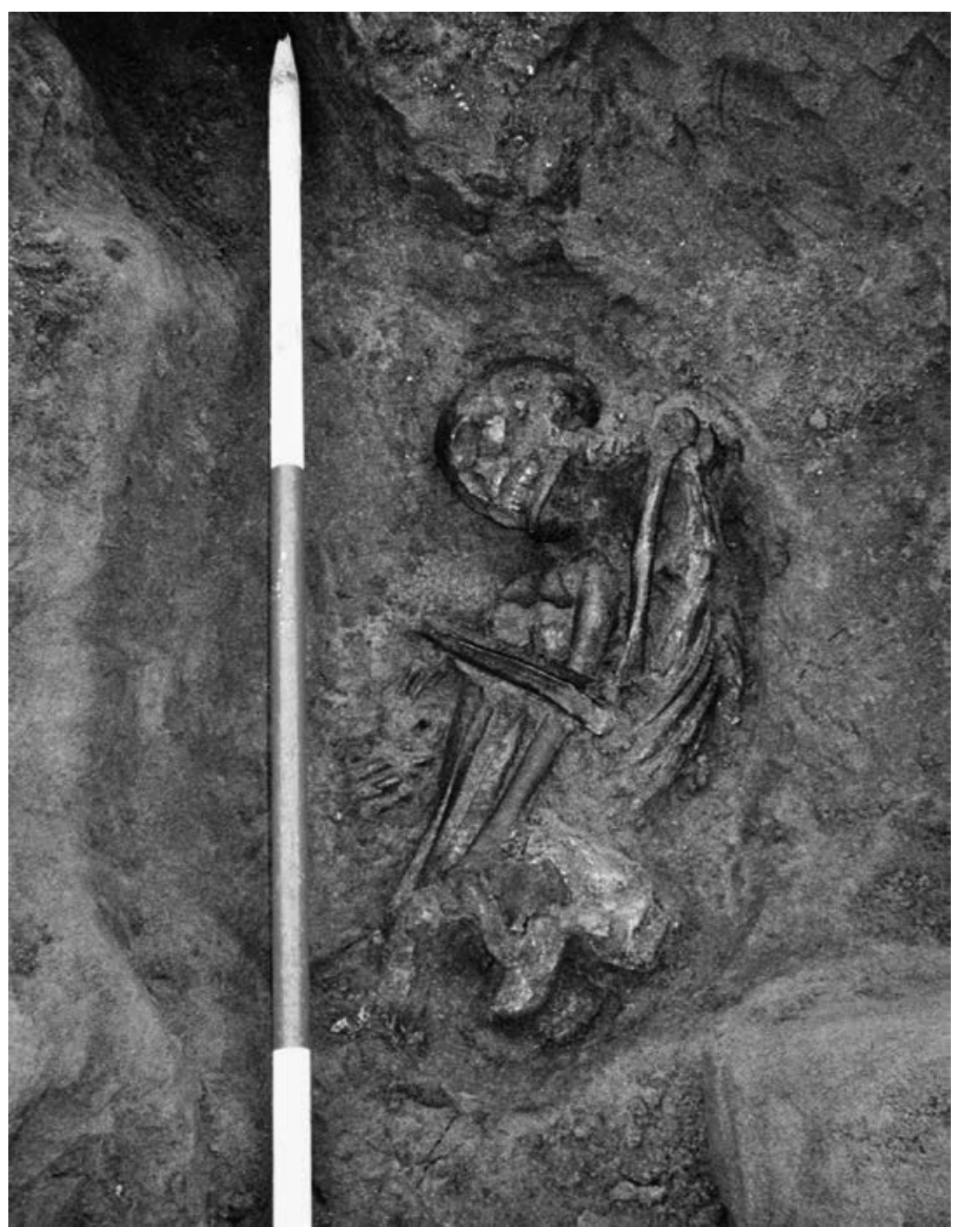

6.2 The Cladh Hallan male bog bod(ies) (a composite, made from three individuals, at least one of whom may have been interred temporarily in a local bog). All rights reserved and permission to use the figure must be obtained from the copyright holder. 
the notion of curated and manipulated bodies has been identified in both further Bronze Age (Booth et al. 2015; Smith et al. 2016) and Iron Age examples (Tollefsen 2016) within the UK. This internationally important discovery reveals that the same knowledge of how to store and cure bog butter was here being used to store and mature a human body: preventing its decay but ageing it in a very particular way that enhanced its potential to merge and make a powerful new body. While so far unique, the Cladh Hallan mummies suggest that the peat bogs of Uist, as well as other environments that inhibited decay, played a significant part in 'holding fast' not just butter but bodies, enabling what we commonly call 'secondary' or delayed mortuary practices. The Iron Age, as Chapter 5 has argued, marks the beginning of experimentation with subterranean storage, bogs, souterrains and pits, salting and smoking. Cladh Hallan is the clue that the preserving properties of the bog were known and manipulated. This was indeed an era where people may have believed they were successfully experimenting with and intervening in time, at least in terms of its effect upon organic matter: giving the living a seemingly supernatural power that enhanced the post-mortem agency of the dead.

What about later periods? An early medieval burial at Jubilee Tower in Lancashire (dating to the seventh century $\mathrm{AD}$ ) seems to follow contemporary burial rites: interred in a woollen shroud with three 'white feathers', the symbolism of which escapes us (Edwards 1973; Briggs 1995: 210). Six fully clothed burials from Culrain (Briggs 1995: 218) may represent a small cemetery, like the coffined burials at Bressay (Hunt 1866a; see also Chapter 2). A touching burial of an infant wrapped in a 'Scotch' bonnet and woollen cloth at Hunstgarth in Harry, dating to the late eighteenth century, is probably also a formal burial; perhaps the child died suddenly or mysteriously - the equivalent of a 'cot death' but s/he may also not have been baptised. Like so many small souls, they may have been excluded from consecrated ground. There was also the issue of cost: for the poorest members of society, a shroud, a coffin or a mass might have been beyond reach, especially at times of dearth, disease or crisis. An 'extraordinary large skeleton' was found in a coffin in the turbary of Mownog, Maes-y-Pandy (Wales, Gibson cited in Camden 1722). Isolated communities (particularly in severe weather) might turn to the bog to control a noisome corpse, or one for whom no one accepted financial or social responsibility. Strangers or foreigners, especially those dying of infection or sudden illness and whose kin and origin were unknown, might also find themselves buried in the bog, as in the rumour of 'Dutchmen' who died of a fever and were supposedly buried in West Liog (Cowie et al. 2011: 10). In addition to these examples, Chapter 2 has shown that by the post-medieval era, mysterious or strange deaths were often treated in non-normative ways due to fears around the post-mortem agency of the deceased (Watkins 2013). Bad priests and restless clerics seem particularly prone to a fate in the mire, at least from the documentary sources - perhaps linked to their medieval/post-medieval reputation as portals to hell. By this time if not before, the bog was a realm in which to exile, control or negate potential revenants. 


\section{Unknown or mysterious death}

For every identifiable cause of death there are multiple examples where this leaves no trace (van der Sanden 1996). Haraldskær Woman (once thought to be the betrayed Queen Gunhilde, described in Asingh and Lynnerup (2007: 300) as the Gutskær Mose bog body) died around the age of forty, in c.490 BC. Her remains have recently been subject to stable isotope analysis that suggests she was brought up in the region where she died, but travelled some distance south into Europe in the last few years of her life (Frei et al. 2015). Sticks were found over each knee and elbow, pinning her into the bog (not driven through the kneecap, cf. Aldhouse-Green 2002: 117) but there is no obvious cause of death. She was buried with a skin cape, three woollen garments, several woollen cords and a sprangtechnique cap with cords covering her hair, which was around $50 \mathrm{~cm}$ in length, representing around four to five years of growth (Frei et al. 2015). Two of these textiles were locally made, but a beautiful chequered garment was non-local (Frei et al. 2015: 99). This led the most recent investigators to note she was obviously well connected and well travelled; perhaps her mobility distinguished her for a different place of burial compared with the majority of her community and the bog was a portal for her last voyage into the afterlife. Alternatively, she may have returned transformed or changed from the journey in a manner that disconcerted her community; bearing new ideas, bad news or illness against which she had no resistance, leading to her 'exile' in death (Frei et al. 2015: 100).

Other bog bodies for whom no obvious cause of death could be found include Auning Girl from Denmark (Fischer 2012: 119), Daugbjerg Man (Fischer 2012: 120) and Søgard Man (Fischer 2012: 124). The bog body from Baronstown West in Ireland, dating to AD 200-400 was found 'dressed' in textile and hide clothing, but like Haraldskær Woman, he was weighted down by at least four large branches (van der Sanden 1996: 92, 99). The iconic Windeby 'Girl' (the front cover for Aldhouse-Green's 2016 monograph) has recently been reidentified as a 'boy' (Gill-Robinson 2007; Fischer 2012: 137), aged around fourteen at the time of death. He suffered from episodic malnutrition and illness during his life, which left their mark in pronounced Harris lines of nutritional stress on the tibia (van der Sanden 1996: 112). His hair had been unevenly cut in two different stages, closecropped. There is no obvious cause of death, but following his demise, he was laid in the bog on his right-hand side, with a skin cape still wrapped around his neck. A 'sprang band' was reputedly found across the eyes like a blindfold, yet this is an openwork, decorative piece, whose crafting method produced a weave with natural elasticity and decorative end tassels. This may well have originally been a hair covering, which had slipped across the forehead or face. Indeed both Asingh and Lynnerup (2007: 305) and Fischer (2012: 136) report that a conservator 'admitted' to placing it over his eyes while preparing him for exhibition, although it originally lay across the middle of his face, inflating the perception of shaming done to this 'little adulteress', as he was once envisioned. If in situ, its original intent might have 
been to stifle or silence the victim, rather than blindfold them from their fate. Thin rods were laid across his right arm, as if in symbolic staking, and four pots were laid close by, suggestive of food or drink offerings. While this is an unusual and disturbing bog body, no obvious cause of death can be seen.

In a similar vein, the appearance of Borremose Woman appals at first sight: her right knee is drawn up and her arms protectively cover her torso, still wrapped in a blanket with leather cord and holes that suggest a 'skirt-like' garment. One hand appears to touch the ruin of her face. Placed prone in the bog, she has now been turned over, where her face appears to have been smashed to a pulp, disguising chin, cheeks and nose. A fragment of facial tissue and hair, supposedly found under the body, suggests she may even have been scalped. Yet concern has been expressed that this damage is due to the pressure and movement of delicate facial tissue from compression by the peat (Asingh and Lynnerup 2007: 299; Fischer 2012: 129). Van der Sanden (1996: 162) also argues this is likely to be a postmortem disfigurement, from the lack of vital reaction in the tissue. The cause of her actual death then, is unknown. However, she lay in an old peat cutting dating to the early Iron Age close to the 1946 male bog body who was hanged (Asingh and Lynnerup 2007: 299; Fischer 2012: 129): we cannot rule out a violent end for her too.

Zweeloo Woman (111 cal BC-AD $240 \mathrm{cal}$ at 95.4 per cent probability, van der Sanden 1996: 191) was most likely laid on her back, as the front of this woman (impaired by a condition such as Léri-Weill dyschondrosteosis or mesomelia, causing foreshortening or selective dwarfism of the limbs, see Bianucci et al. 2012) was badly damaged by the peat diggers and more poorly preserved. She too was placed in a pit or bog pool whose peat was earlier than the interment of this thirty-five to fifty-year-old woman. This might suggest a more formal burial she had recently eaten a millet-based porridge flavoured with blackberries, which places her death in the early autumn (van der Sanden 1996: 91, 11). Yet like Windeby Boy, her hair had been recently cut to a short length of $2.5-3.5 \mathrm{~cm}$ (van der Sanden 1996: 164). Twenty-one sharp-force cut marks have recently been identified on the skeletal remains, clustered around the left shoulder, right elbow, left hand and upper and lower legs (particularly on the right-hand side), with a large cut mark observed above the left orbit on her forehead (Bianucci et al. 2012: 54, figs 9 and 11). None of them showed bony reaction or healing, meaning they are peri- or post-mortem cuts that would have been intensely painful but not fatal. Yet the focus upon the joints is odd: there is curiously no evidence of 'equivalent injuries on the body surface' (i.e. corresponding cuts through the skin and tissue), apart from a possible open wound on the posterior of the left shoulder. What looks like multiple wounding could all be post-mortem 'damage' (Bianucci et al. 2012: 54-5). Given the separation of skeletal elements from her exterior flesh and viscera, it is highly likely that this is the result of quite coarse post-mortem style preparation of the body parts, for analysis and museological display during the 1950s (Bianucci et al. 2012: 54-5). 
Huldremose Woman from Denmark, dating to c.350 BC, was dressed in a linen or nettle-fibre undergarment (probably not made locally, see Frei et al. 2009), a long blue woollen skirt and a red check-pattern scarf (running from neck to under her arm and fastened with a pin made from bird bone). The stable isotope signature of the wool suggests one locally made source but an exotic origin for the other two wool types (possibly in Norway or Sweden, see Frei et al. 2009). She may therefore have moved into the region, possibly through a marriage alliance, or else was wearing the powerful evidence of her distant connections. In addition, she wore two skin capes: an inner lambskin cape turned fleece inwards and an outer brown sheep hide turned fleece outwards, which would have helped shed water (National Museum of Denmark 2019; see Figure 6.3a). The lambskin inner cape contained a sewn-up 'secret pocket' in which were placed a beautiful horn comb and a thin blue 'hairband' leather cord, wrapped in a bladder, interpreted as an amulet cache, integral to this old, patched cape (Frei et al. 2009; see Figure 6.3b). On her chest lay a single willow stick. A mark around her finger suggests she habitually wore a ring that also went into the bog, but this was never reported and may have been pocketed on discovery. Another cord necklet was strung with two amber beads, which also went missing (van der Sanden 1996: 93). Like Zweeloo and Windeby, her hair had recently been cut to within a few millimetres and the hank laid next to her in the bog (van der Sanden 1996: 164; Asingh and Lynnerup 2007: 296). A single lock of hair was tied up with a woollen cord and wrapped, several times, around her neck. Yet there was no sign that this was a strangulation. A severe cut or fracture of her left upper arm, severing it above the elbow, has for many years been interpreted as a violent amputation, resulting in the laying down of this limb next to her (van der Sanden 1996: 162). Yet recent re-evaluation suggests it could again be post-mortem damage during peat cutting, discovery or even transportation off-site (Fischer 2012: 117; National Museum of Denmark 2019). An apparent cut wound on her right foot, shown in X-ray in van der Sanden (1996: fig. 228), is more difficult to explain away; it could be a classic 'disabling' wound to prevent a victim fleeing. Other authors disagree as to whether there were further cuts (Asingh and Lynnerup 2007: 296) or a healed fracture to the right lower leg (Fischer 2012: 117). She had recently eaten a soup or casserole, made from coarsely ground rye mixed with spurry and evidence of some meat (van der Sanden 1996: 110). The relative lack of weed species suggests a reasonably wellcleaned cache of grain (apart from the spurry crop, seen as a poor man's substitute: probably used to eke out the rye, see van der Sanden 1996: 110). Although she was not accorded the local Iron Age rite of cremation, there is no reason therefore to believe she did not due of natural causes; perhaps (like Haraldskær Woman) her powerful reputation or exotic status required a distinctively different place of burial (National Museum of Denmark 2019) or perhaps the hidden cache suggests she was perceived as a seer or witch-like figure who needed to be controlled or appeased by burial in the bog (Lund 2002). 


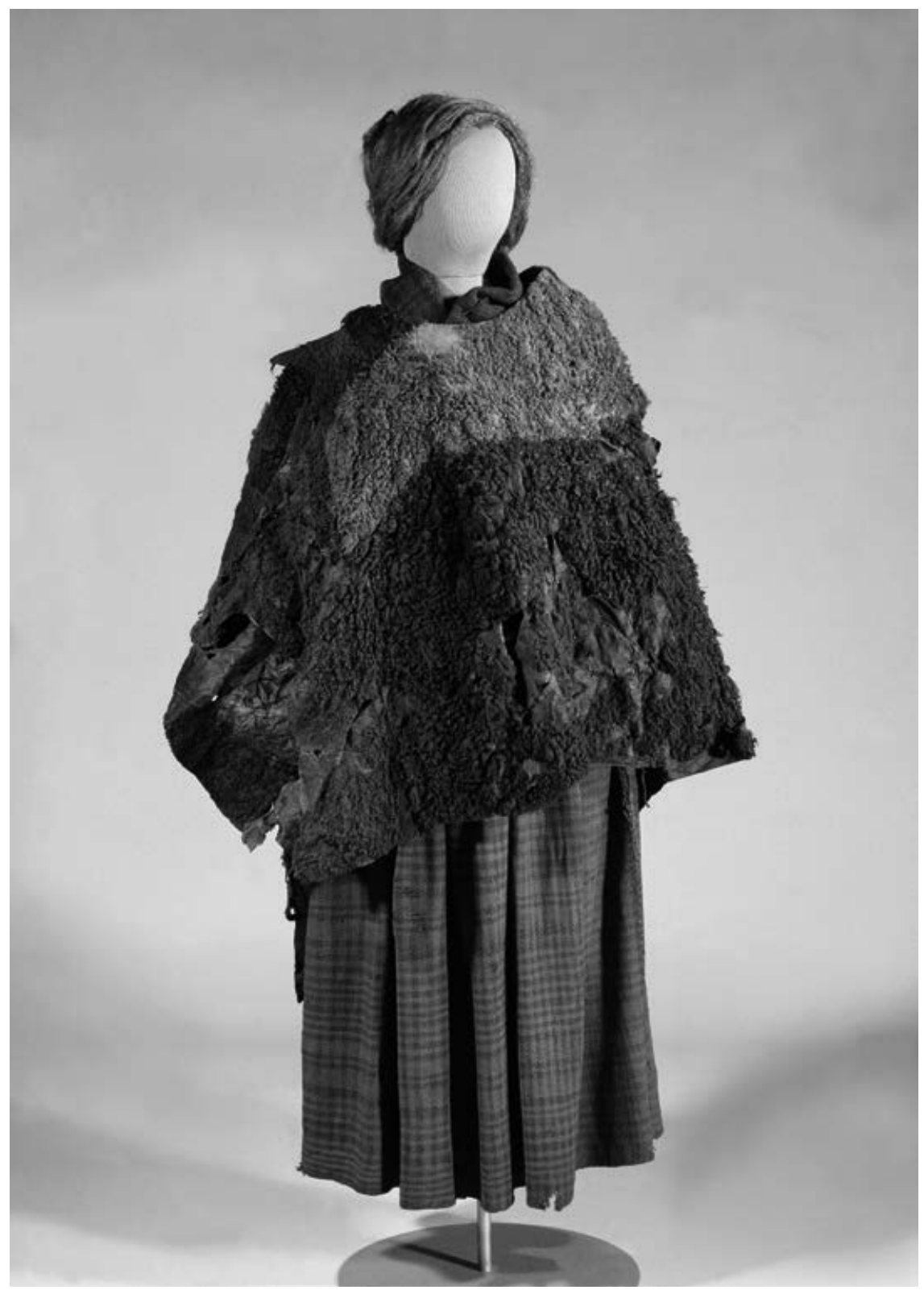

6.3a The Huldremose textiles. All rights reserved and permission to use the figure must be obtained from the copyright holder. 

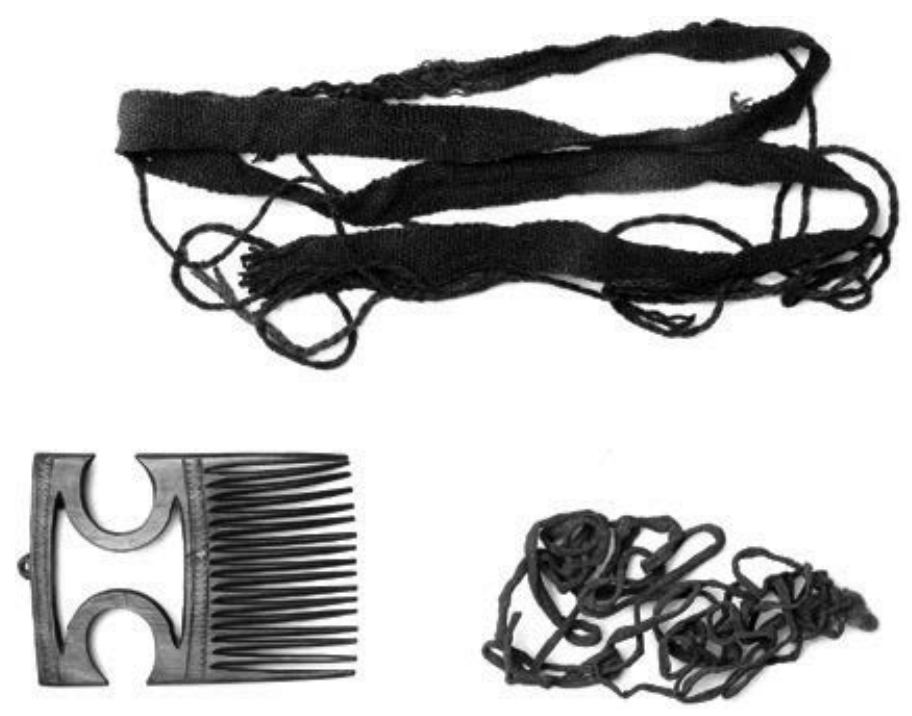

6.3b The Huldremose hidden possessions. All rights reserved and permission to use the figure must be obtained from the copyright holder.

\section{Sharp- and blunt-force trauma}

Against these other categories we can now place bog bodies where there seems to have been a greater degree of trauma that needs careful consideration as to whether this is the result of accident or a more orchestrated and premeditated 'ferocious, controlled violence', both ante-mortem (before death) and peri-mortem (around the time of death, see Taylor 2008: 145). Rendswühren Man from Germany (95 cal BC-AD 140 cal, at 95.4 per cent probability, see van der Sanden 1996: 193) appeared to have sustained a major blow to his face, affecting his nasal bone, right orbit and through into the temporal and parietal bone (Asingh and Lynnerup 2007: 308; Gill-Frerking 2014: 68). While there is a possibility this is peat bog compression damage, the covering of his head by a woollen blanket and fur cloak might have been designed to cover and wrap the disfiguring trauma. Leather 'anklets' might be remnants of clothing but they might equally be modes of hobbling or restraining him in life or indeed, in death.

The other infamous example of apparent 'restraint' is the Kayhausen boy from Germany, aged somewhere between eight and fourteen years of age, who died between 363 and 88 cal BC (at 92.4 per cent probability, see van der Sanden 1996: 192). He may have had a severe infection to his right hip: the X-ray shows an abnormal change in the 'neck' of the femur (van der Sanden 1996: 141). If it is the case, he would have had impaired mobility at the time of his death. All we know 
about the rest of his life is that he had eaten a wild apple shortly before his death, as two pips were found in his stomach contents. A stab wound to his left upper arm and three 3-4 cm slits in the throat area were probably the cause of death. He was then bound up: strips of woollen fabric were used to tie his arms behind his back and another strip was wound around his neck, passing front and back, through his legs, while his ankles were also bound by a repurposed cape (van der Sanden 1996: 93, fig. 117). The fabric shows no sign of tearing or slashing meaning that this binding followed the stabbing and may simply have been a means of carrying a 'packaged' body to the bog. Yet the binding seems very similar to the 'hog tie' position used to torture or even strangle a prisoner. The hastening of his death could have been brought about by linking the ankle binding to his hands, forcing him to maintain an arched back for as long as possible until he self-strangled. Such a fate for a young man seems immeasurably cruel. Yet child sacrifice to appease the gods and ensure fertility is not only well attested in the Andean child mummies but also in the contemporary cult of Nigerian 'muti' (Taylor 2008: 8). (The death and mutilation of a Nigerian boy known only as 'Adam', found in the River Thames in 2001, has been attributed to this cultic activity, designed to create potent medicines from its young victims' remains, see Cowan 2004). In Things Fall Apart, the author Chinua Achebe (2006) tells a fictional story of a young boy, Ikemefuna, given to a powerful chief as part of a peace settlement. Despite his admiration for the captive (who spends several years with this family and forms strong bonds with them), a prophecy from a village oracle determines that the child must die, and although the chief is warned to have no personal part in this killing, his desire to show his masculinity at the moment of murder overrides his relationship with the child. Once his own machete is wielded against the sacrifice, it heralds his own decent into misfortune and eventual suicide (Achebe 2006). Lest we think this is merely the stuff of fiction, in early Iron Age Lewis at Hornish Point, four pits under a roundhouse contained the quartered remains of a boy of about the age of twelve, interred with the remains of two young cattle and sheep: a foundation deposit that reeks of a fertility offering (Barber et al. 1989; James and McCullagh 2003).

So-called 'cult' sites, where multiple human remains were deposited (often in a fragmentary state) include the bog of Oberdorla (Germany), where the remains of over forty individuals were found in among anthropomorphic posts, bundles of flax, wheels and agricultural implements, pottery sherd clusters, animal bone, worked wood and charcoal spreads. The context was a lake infilling with peat, used from the early Iron Age into the Middle Ages (van der Sanden 1996: 104). Such a site, with protracted deposition of fragmentary human remains often showing evidence of violence, has more in common with the prehistoric causeway and platform sites of the UK such as Flag Fen (Pryor 2005), Fiskerton (Field and Parker Pearson 2003) or Over (Evans et al. 2016). At all of these sites a mix of artefactual, faunal, avian and human remains in relation to platforms, raised timber structures and causeways suggest repeated wetland deposition at riverine sites that were growing in both fluvial activity and ritual intensity during the Iron Age. Evidence 
for violence and/or dismemberment is sometimes clear but discerning between peri- and post-mortem cut marks can be difficult, partly because bone remains more 'plastic' in these wet environments for longer. The excarnation of a revered ancestral body that needed to dissipate back into the world through the action of wind, weather, corvids and scavengers, cannot necessarily be discerned from the triumphal display of an enemy's corpse. As on many Iron Age and early Roman dryland sites, a mix of trophyism, sacrifice, ancestral veneration and mortuary disposal complicates our understanding of apparently violent or messy treatments of the corpse.

\section{Hanging and strangulation}

However, there are remains where the manner and circumstances of death are clearer. Gallagh Man from Ireland, found in 1821, was discovered interred in a skin cape and stakes pinning either side of the body down into the bog. Dating to 400-200 BC, he was found with a 'band of sally (willow) rods' around his neck, assumed to have been used to asphyxiate him (van der Sanden 1996: 73; Kelly 2013). Windeby Man (an early Iron Age bog body, c.400-300 BC) also appears to have been strangled by a hazel branch the thickness of a finger, wound around his neck (van der Sanden 1996: 157). His arms were folded across his chest, perhaps composed after death, and he was 'anchored' in the bog by no less than eight hefty wooden stems and stakes (van der Sanden 1996: fig. 130; Asingh and Lynnerup 2007: 306). The 1946 discovery of Borremose Man from Denmark reveals he dated to the earlier Iron Age, around the eighth century BC (Asingh and Lynnerup 2007: 297). His last meal was a poor gruel, consisting mainly of weed species, with a little animal hair (possibly a contaminant or the residue of animal tissue) and bog moss leaves (van der Sanden 1996: 108). He appeared to have died from major trauma to the back of the head (van der Sanden 1996: 108), but this has recently been reinterpreted as post-mortem damage from the pressure of the peat (Fischer 2012: 125). Instead, a halter made of three-ply bast or hemp rope suggests he was strangled: the cord measured a total length of $94 \mathrm{~cm}$, its ends reinforced with a knot and leather terminal to prevent fraying, with a sliding knot to tighten the noose (van der Sanden 1996: 156). This was an object that had been made with some care. He was interred with two sheepskin capes placed in a bundle at his feet. The undated bog body of Kreepan Man from Germany was also found face down in the peat, with a 'cord of entwined oak and birch twigs around his neck and arms' as well as small 'clamps' above the feet, which might suggest his ankles too had been bound together (van der Sanden 1996: 89). Three large stones (weighing 20-25 lbs) were found in association with two oak sticks and twigs, suggesting he may have been weighted down in the bog - perhaps asphyxiated by both strangulation and suffocation in the mire. Other 'hanged' bodies probably include Krogens Møllemose, dating to $300 \mathrm{BC}$, found with a leather ring analogous to a large dog collar but thought to be a noose (Fischer 2012: 116). He was 
associated with at least one skin cap and textile fragments that might have represented a bag. Lykkegårds Mose Man was also found with a 'two-ply cord' around his neck (Fischer 2012: 124).

It is not just men who met with such a fate. Elling Woman from Denmark, aged around twenty-five years when she died in around 205 BC (Asingh and Lynnerup 2007: 297), was found close to Tolland Man. She was wrapped in both a sheepskin cape and a cape made from cowhide, with a further cowhide cloak wrapped around her legs. She had a hair braid running to $90 \mathrm{~cm}$ in length, fastened in a complex knot. A $40 \mathrm{~cm}$ length of woven sheep wool, possibly a belt, was found nearby, which van der Sanden (1996: 155) argues was probably used to strangle her, leaving a deep 'V-shape' furrow embedded in the flesh of her neck and throat. This most domestic of clothing items has historically, of course, often been turned into a weapon of punishment: the belt used here had a sliding knot to facilitate tightening to the required degree, traditionally placed at the back of someone's neck (van der Sanden 1996: fig. 223). Yde Girl from the Netherlands was around sixteen years of age when she died, already warped by the severe scoliosis that had twisted her spine (van der Sanden 1996: 83 and 161). The original position in which she lay is impossible to discern but given that the face is better preserved, she may also have been placed prone in the bog. The left-hand side of her head was completely shaved shortly before death but the right-hand side was up to $20 \mathrm{~cm}$ in length, with the cut-off hank of hair apparently laid alongside her in the bog (Asingh and Lynnerup 2007: 302), suggesting an ante or peri-mortem radical alteration in her appearance. She was covered by a woollen cloak, concealing a stab wound near the left clavicle (van der Sanden 1996: 161). A twisted woollen sprang band $220 \mathrm{~cm}$ in length (perhaps a waistband or hair covering, woven for elasticity) was found wound around her neck three times, its sliding knot indented below her left ear, suggesting strangulation like Elling Woman (van der Sanden 1996: 161).

The iconic bog body of Tolland Man himself (Figure 6.4) was around thirty years old when he died, c.405-380 cal BC (Nielsen et al. 2018). He was not particularly tall, measuring $c .1 .61 \mathrm{~m}$ (5 foot 2 inches) in height (though the bog has probably shrunk the remains a little), with damage to the sole of his right foot, which showed scars from some kind of penetrative injury (van der Sanden 1996: 135). He had eaten a last meal made from barley, oats and the mix of wild weed species to be expected from prehistoric harvesting, oily flax and gold of pleasure seeds, fat hen, sandy grit (probably from the rub of the quern stone used to mill it) and bog moss leaves, possibly from cooking with or drinking bog pool water (van der Sanden 1996: 108). There were fungal smut spores suggesting some contamination of the cereals (van der Sanden 1996: 11). The episode of Buried Treasure discussed in Chapter 2 ended with Sir Mortimer Wheeler and Glyn Daniel 'tasting' a version of this last meal, which they found abhorrent: 'No wonder the poor chap committed suicide if that was the sort of cooking he got at home!' Sir Mortimer Wheeler wittily added. (It is all a matter of taste: prehistoric people had very different expectations from their diet - a version of this 
meal that I tasted during a visit to Silkeborg Museum was in fact delicious and sustaining - much clearly lay in the preparation.) He was apparently naked apart from a beautifully made sheepskin leather cap, stitched from eight pieces of hide and fastened tight around his head, its small bow tucked neatly under the right temple (Fischer 2012: 43). An unevenly cut belt with a loop knot was fastened around his waist, which may suggest an inner garment that has not survived, yet no textile impressions of linen or plant fibre were observed on the skin (Fischer 2012: 43-4). The method of his death seems clear: a plaited leather thong, 1.25 $m$ in length, was found around his neck, and had left clear impressions in the flesh, under the chin and at the sides, suggesting the knot was at the back (van der Sanden 1996: 155). The length of this rope might suggest suspension from a gallow or a tree: hanging rather than strangulation, as reconstructed by Niels Bach for Silkeborg Museum. The end of the rope was severed where it had apparently been 'cut down'. Hanging and strangling literally took the breath away from the body, perhaps a vital moment of curtailing the animus of a human being (Taylor 2008). Hanging suggests a more public spectacle, raised for others to see, while strangulation was at the hands of another, depriving the victim of their life. While suicide or murder is a possibility in some of these cases, execution for punishment or sacrifice (of men and women, young and middle-aged) seems more plausible given the prepared nature of the materials used and the force required.

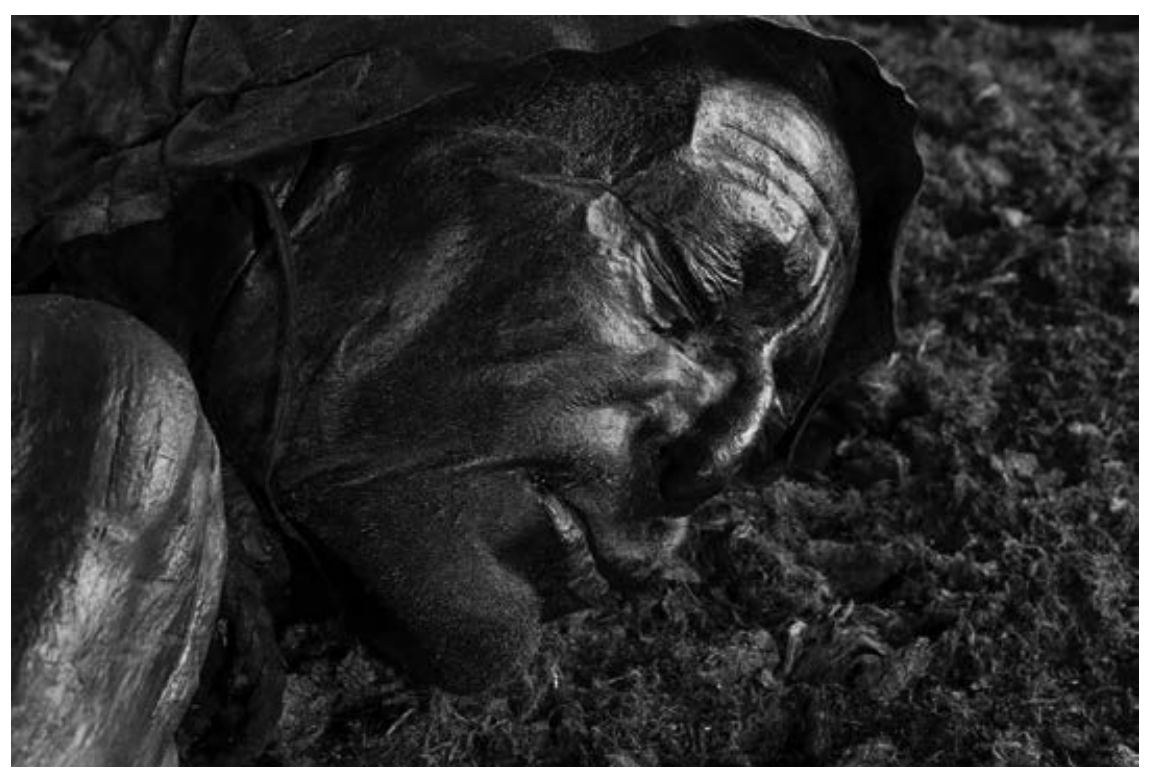

6.4 Tolland Man. All rights reserved and permission to use the figure must be obtained from the copyright holder. 


\section{Bloodshed}

In contrast to the cessation of breath, Aldhouse-Green (2002) has suggested that the spilling of blood in a dramatic and vivid performance may have been key to sacrificial rituals. One of the other iconic Danish bog bodies, Grauballe Man, was in his late twenties to early thirties when he died, sometime between 400-200 BC. He was of average but not impressive stature and he had hair of around $15 \mathrm{~cm}$ in length, neatly cut across (probably with small shears) and both a beard and a moustache around $1 \mathrm{~cm}$ in length (Asingh and Lynnerup 2007: 196, 230, 231). Stable isotope data from the hair suggest a terrestrial-based diet in the last few months of his life, based more on animal than plant matter (Asingh and Lynnerup 2007: 195). His teeth not only showed wear but infection from periodontitis, with loss of one of his front incisors ante-mortem (Asingh and Lynnerup 2007: 32 and 146) as well as enamel hypoplastic defects on his permanent dentition indicative of stress or malnutrition around two to four years of age (Asingh and Lynnerup 2007: 150), possibly coinciding with weaning. His last meal was very similar to Tolland Man: quite a large quantity of a gruel or thin soup, unfortunately a little burned, made from a mix of $c .20$ per cent cereal grains (wheat and barley) along with 80 per cent weed species (including persicaria and corn spurry). The latest analysis of this material (by Harild, Robinson and Hudlebusch cited in Asingh and Lynnerup 2007) suggests that this was largely a by-product, the threshing floor gleanings of a few grains and weed contaminants from the field, as well as sandy grit from unwashed plant matter or the quernstone and bog moss leaves from drinking water or soup mix (Asingh and Lynnerup 2007: 160): no carefully prepared ritual meal, this dish was 'poor and unpalatable' yet nonetheless of some nutritional value (Asingh and Lynnerup 2007: 174). Splintered bone, fine animal hair and carbonised matter suggest that meat - possibly pork - had been added to his dish, perhaps in an attempt to add some flavour (van der Sanden 1996: 108), making up for the thin fare and in keeping with the meat-rich diet he seemed used to, as indicated by the stable isotope analysis of his hair (Asingh and Lynnerup 2007: 195). Alongside the smut spores of slightly contaminated cereals, traces of ergot were found, probably derived from infected 'Yorkshire fog' grass mixed in with harvested crops (Harild, Robinson and Hudlebusch cited in Asingh and Lynnerup 2007: 176). Much has been made of this discovery. The likely mistranslation of the original Danish report seems to have inflated 'some' to 'many' sclerotia, leading to claims that Grauballe Man might have suffered from symptoms known colloquially as St Anthony's Fire - hallucinations, convulsions and burning sensations in the mouth - which could eventually lead to 'dry withering ... the limbs rot in their joints, [and] turn the colour of lead', as one eighteenth-century text puts it (Asingh and Lynnerup 2007: 118). This was the medical condition of gangrene, from which there would have been no release. Yet the most recent estimates suggest the amount falls into current European Union (EU) permitted limits for commercial grain. While this re-evaluation was necessarily based on a sample, we have no way of knowing if it had any effect upon Grauballe Man. It is tempting to think 
so: such symptoms would have shocked and horrified his community, leading to abnormal behaviour and suffering they could not alleviate. If they knew the end of this disease, they also knew it was not a good way to die, rotting from the inside out - turning his death into something of a mercy killing.

Yet we must accept this is now unlikely to be the case and look to other reasons to explain the manner of his actual demise. This was brought about by a gaping blade wound to his throat, cut practically from 'ear to ear' (Fischer 2012: 133), probably running from left to right (delivered from behind, with the head inclined backwards), with a noticeable 'notch' midway that suggests the jagged or jerking pull of the blade, repositioning and deepening its cut (Asingh and Lynnerup 2007: 254). This was a thorough and professional job that was designed to be fatal within a few minutes, cutting through the oesophagus and severing the two carotid arteries and jugular vein, but leaving the lower throat area of larynx and hyoid bone intact (Asingh and Lynnerup 2007: 128 and 252). Severe haemorrhaging and the flooding of blood into the respiratory system would have quickly affected oxygen levels, bringing on unconsciousness. The 'skull fracture' once thought to indicate a head wound has recently been dismissed as post-mortem damage to the body during its discovery by someone who admitted 'treading' on the skull (Asingh and Lynnerup 2007: 17 and 117; Fischer 2012: 132)! However, an oblique fracture of the tibia, leading to a sharp-force splintering of this bone and blunt exterior trauma, appears to have been inflicted around the time of death, about $10 \mathrm{~cm}$ below the knee, causing some rotation of the distal part of the leg. This was confirmed in the new CT scanning and radiological investigation (Asingh and Lynnerup 2007: 120 and 258). Post-mortem damage that affected one and not both leg bones seems unlikely; he may have been brought to his knees with a savage blow from a blunt object that fractured his shin bone and took his legs out from under him. The bold cutting of his throat seems to fit the requirements of a 'blood sacrifice' in all of its brutality (Aldhouse-Green 2002: 87), yet it was also a swift and impressively gory end to a life. He was laid prone in the bog but slightly raised, as if sunk on to a slightly convex surface, the obverse of contemporary supine burial (Asingh and Lynnerup 2007: 240). Fascinatingly, the latest analysis has demonstrated that the plant roots that penetrated the body were a couple of hundred years younger than the corpse (Asingh and Lynnerup 2007: 214) - confirming Godwin's theory on one of the reasons why radiocarbon dates of such bog plant matter may not match the body (see Chapter 4).

\section{Dismemberment and decapitation}

The deliberate 'cutting up' and separation of body parts is well attested from bogs across northern Europe. In Britain, Lindow I (thought to be a female head) and Lindow III (the majority of an adult male body) are currently believed to represent two complementary body-part deposits (Joy 2009), telling us of the violent separation of torso or trunk from crania. Two decapitated heads were found in Wales, 
from Melmyd Avenue (Clwyd) and Giffron (Powys): the latter found 'with full complement of hair' (cited in Turner's 1995b: cat. nos 61/2 and 66/1 respectively). The head of Stidsholt Woman (dating to around 300 BC) had a full head of hair wound up into a beehive setting and held in place by a woven hair band. She was found wrapped in a skin cape, decapitated from back to front between the third and fourth cervical vertebrae (Fischer 2012: 115). The Roum head, also believed to be female (from the lack of facial hair) and dating to around AD 1, was wrapped in a sheepskin cape (van der Sanden 1996: 159; Fischer 2012: 120). The Pilling Moss head from the UK, again thought to be female, was interred with two strings of cylindrical jet beads, one amber bead and abundant plaited hair, head, neck and necklaces wrapped in a woollen cloth (Fischer 2012: 210). Along with Lindow I, Roum and Stidsholt, she is further evidence that decapitation was not just a fate suffered by men, and spanned the Bronze Age to the Roman era.

The male Osterby head from Germany was also wrapped in a cape or sack made from roe-deer skin (Asingh and Lynnerup 2007: 241) and was clearly fleshed at the time as both cranium and mandible are present. This individual is famous for his distinctive hair colour, stained by the bog to a brilliant amber, and his hairstyle, known as a 'Suebian knot' (van der Sanden 1996: 91; see Figure 6.5). This design was mentioned by Tacitus in Germania (Mattingley 1970: 38) as a distinctively masculine arrangement for long hair among the Suebi: partly to distinguish status, both freeman from slave, but also youth from age, and the most elaborate hair arrangements were reserved for their chiefs. Tacitus is at pains to argue this is not the result of vanity but rather 'to appear tall in stature and to inspire fear' - adorning themselves 'for their foe' (cited in van der Sanden 1996: 145). A sharp-force blow had left its mark just above the right orbit and he had been decapitated at the second cervical vertebra (Asingh and Lynnerup 2007: 246 and 309). This wrapping of a decapitated head suggests not only the disguising of the face and its fate from view but perhaps also a parcelling up to transport the head to the bog. Such isolated heads need not necessarily imply 'aggressive, predatory headhunting', as Armit (2015b: 591) points out, for the taking of heads is a 'malleable phenomenon, varying in its nature, intent, and intensity over time'. Yet as Armit (2015b: 591) goes on to acknowledge, the metaphysical and symbolic power of decapitation almost always concerns 'the creation and maintenance of social power', especially among 'emergent elites'.

The most recent Iron Age Irish discoveries show a similar tale of violence and dismemberment. Clonycavan Man died around 392-201 BC. He was not a tall man, but had both a beard and impressive hair: selectively shaved at the front and cut short at the back, with lengths of up to $20 \mathrm{~cm}$ of hair scraped into a 'topknot' (Kelly 2013: 234), although the original reports of the use of a Mediterranean 'pine resin' hair wax have now been discounted (Mulhall pers. comm.). Given the cutting of other bog body hair, we must consider whether this was a self-preparation (part of how he made himself intimidating to his enemies as in the Suebi) or if this was part of the ritual preparation - even humiliation - prior to his death. He had consumed quite a high plant-based diet in the last few months before his death, suggesting this may have occurred in the summer months (Mulhall pers. comm.). 


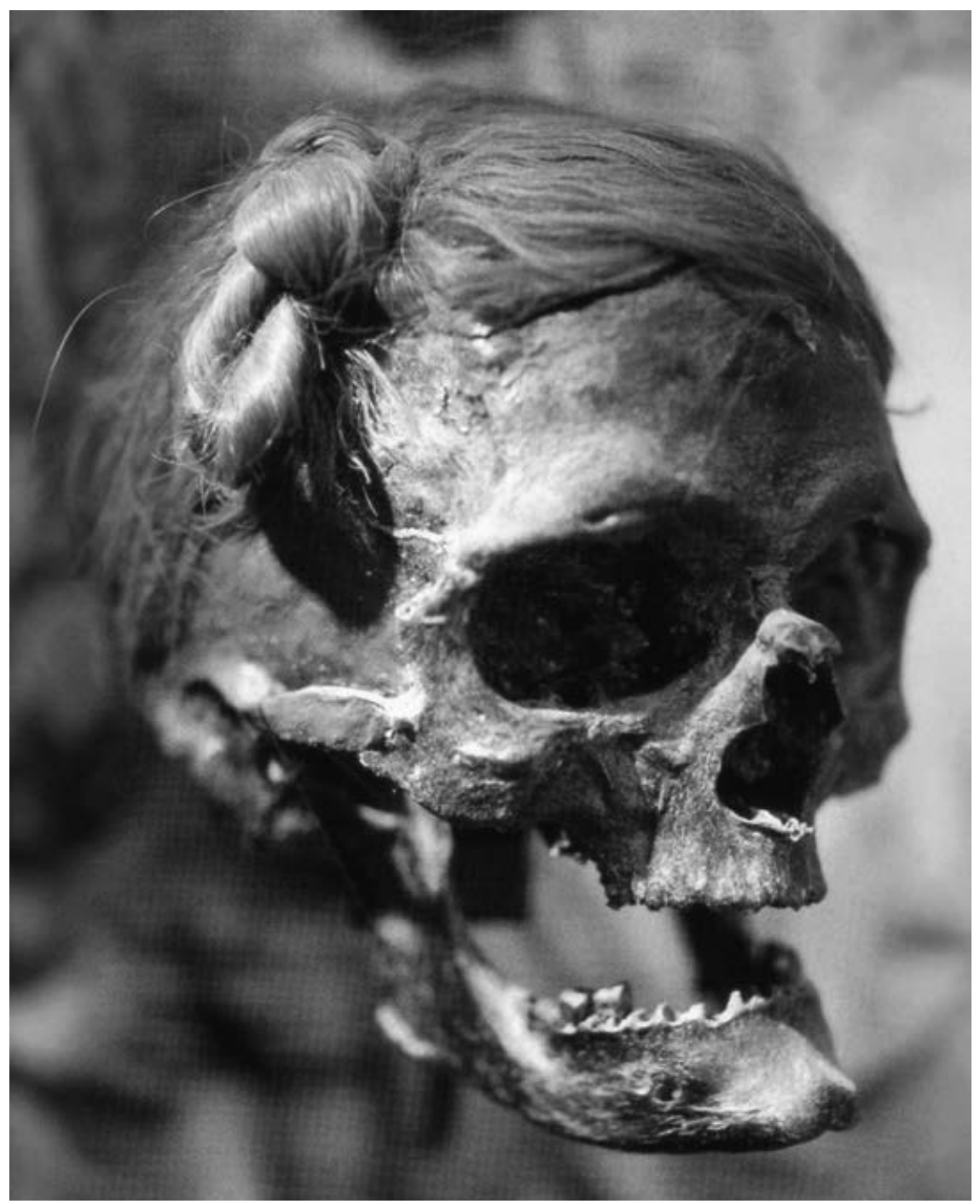

6.5 The decapitated head from Osterby, displaying both the sharp-force trauma above the right orbit and the impressive Suebian knot hairstyle. All rights reserved and permission to use the figure must be obtained from the copyright holder.

A large, sharp-force and crushing blow to his head coupled with several to his chest suggests the use of an axe to kill him, probably delivered from the front, while he knelt before them (Mulhall pers. comm.). The $40 \mathrm{~cm}$ long sharp-edged wound in the stomach suggests that disembowelling followed soon after and the body was separated from the rest of the pelvic girdle and legs (Figure 6.6). 


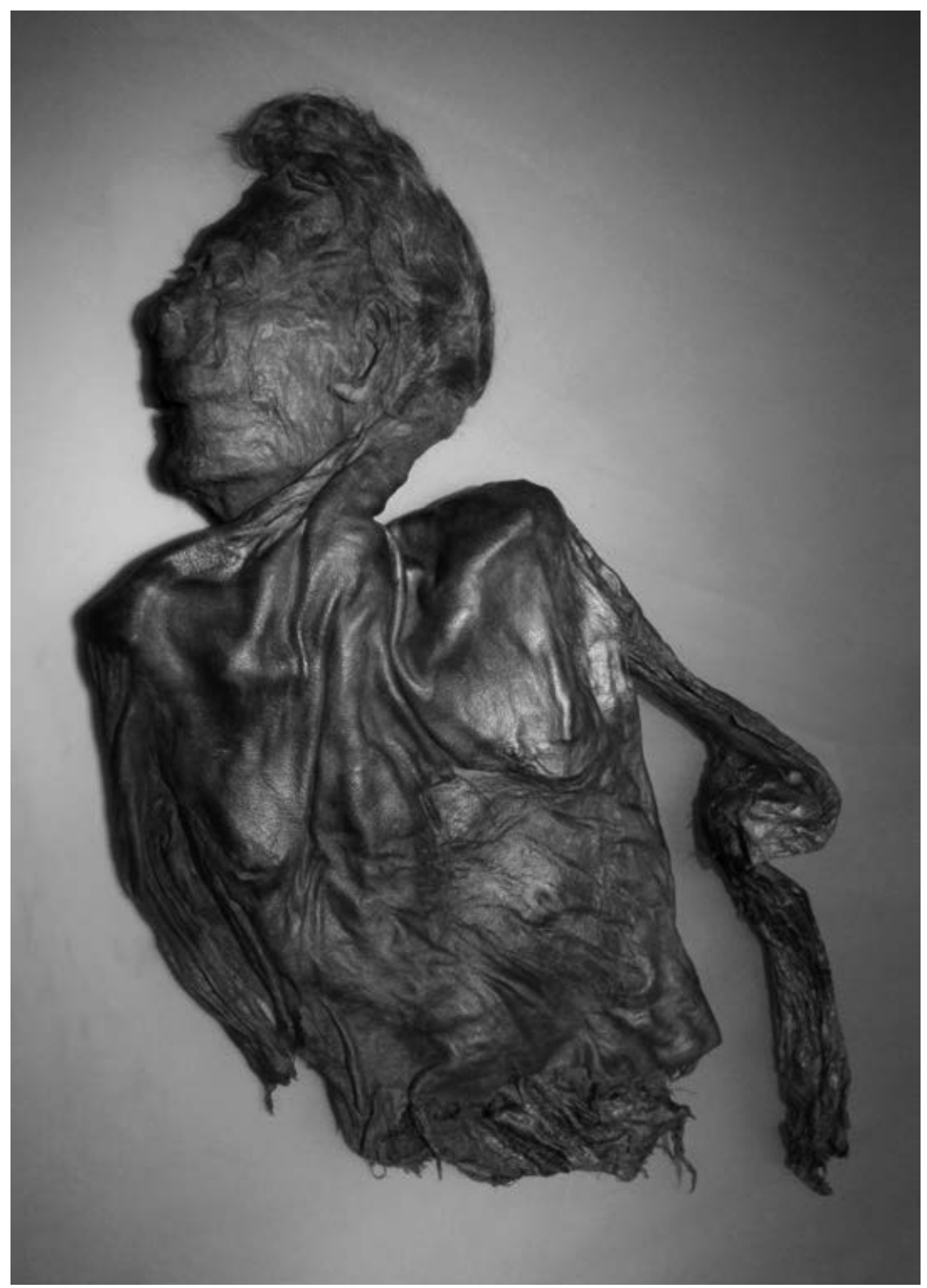

6.6 Clonycavan Man. All rights reserved and permission to use the figure must be obtained from the copyright holder. 
In contrast, only the torso and arms of Old Croghan Man were found deposited in a bog pool somewhere between 362 and 175 BC (Kelly 2013). He appears to be of impressive stature at around 5 foot 11.5 inches (Kelly 2013: 234; Mulhall pers. comm.), wearing a small, slit-braided hide armband: decorated with impressed 'dot and circle' style copper alloy clamps, positioned on his upper left arm. Stable isotope analysis suggests quite a high meat-based diet in the last four months preceding his death (indicative perhaps of a winter demise), yet his last meal consisted of buttermilk and ground rye cereal (Kelly 2013). His fingernails appear well cut and manicured with little evidence of scarring that might be expected of rough agricultural labour (Mulhall pers. comm.). Despite this apparently advantageous life, he may have been tortured before his demise: both nipples appear cut by clean, clear incisions that show no signs of tearing and are not fully detached (Mulhall pers. comm.). It has been suggested that this too is the result of postmortem damage in the bog - similar 'cuts' were also noted on Clonycavan Man but if so, this very selective and clean tearing has not been reported so far from any other bog body. A deep, fatal stab wound to the left-hand side of the chest appears to have been the cause of death and an incision on the left arm appears to be a classic 'parry' wound, attempting to ward off an armed adversary. A final deep tear or graze on the left elbow might have been sustained during the manhandling of the victim or his corpse around the time of death (Kelly 2013). Together, the injuries suggest a frontal attack by a right-handed assailant, before he was decapitated: his thorax was severed from his chest and he was then disembowelled (Kelly 2013: 236). Deep slits were then made in both upper arms, through which were pushed woven withies made from two-year-old hazel wands: Kelly (2013: 236-7) interprets these as 'spancel bands' - the small hobbles used to tether animals from straying or keep them still while milking, which in Irish folklore led to symbolic associations with fertility and the notion that these objects could protect boundaries (Figure 6.7). His dismembered remains were thus quite literally 'tethered' to the bog, perhaps speaking of the fear that he might rise again or harnessing the power of his life and drama of his death to the fecundity of the place.

Other bog bodies found in this recent spate of Irish discoveries include one of the earliest known: the contorted body of Cashel Man, dating to the early Bronze Age; the late Iron Age/Roman era remains of Derryvarroge Man and the early medieval Cloonshannagh body. Full dating and interpretation of these internationally significant interments, and the circumstances behind them, is eagerly awaited. Meanwhile, the only other late Bronze Age/early Iron Age bog body (753-409 BC), Moydrum Man, was so mangled by the peat extraction process that no obvious cause of death can be identified. Nonetheless, he tells a fascinating tale of a last meal of over two to three hundred sloe stones (Prunus spinoza), ingested shortly before his death, which made for a most dramatic X-ray. The cyanide content of the sloe stones is probably negligible given that the pips appear intact but the symbolic importance of the blackthorn in Irish Celtic mythology led Kelly (2013) to suggest this was a symbolically loaded but unpleasant last meal, forcibly ingested as a humiliation to a 'failed king. Using evidence of inauguration rites 


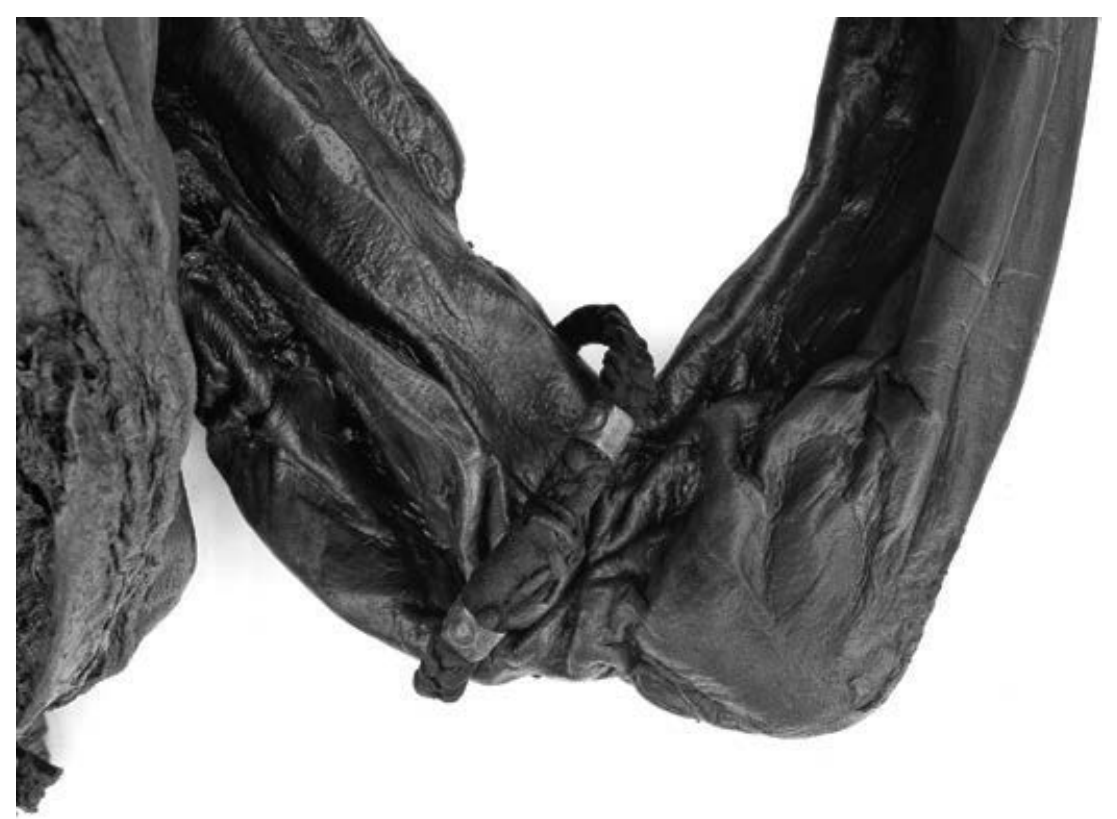

6.7 Old Croghan Man's armlet. All rights reserved and permission to use the figure must be obtained from the copyright holder.

from early medieval texts, Kelly (2006) argues that these prestigious bodies represented leaders who had presided at a time of crises. Their symbolic 'marriage' to the land was perceived to have failed, perhaps due to famine, poor weather, disease or conflict. In order to usher in a new leader and a new era, the relationship between sovereign and land had to be violently severed and the remains deposited at significant boundaries of these small kingdoms (later fossilised as medieval 'barony boundaries'). This novel interpretation has merit, not least because it alters our vision of the bog bodies not just as lowly scapegoats or rather wretched sacrifices, but powerful, even sacred or semi-divine sovereign beings. It also features the bog as a place of sacred communion with supernatural forces, a role strongly supported by the extensive deposition record from Ireland discussed in Chapter 5. Yet in relation to the sloes we must again question our own palette. Once the frost has begun to break down the outer skin of this fruit, and especially in dried form, it can be more palatable: it was used as an important source of vitamins at a time of dearth or on the move and a key homeopathic medicine in many ethnopharmacological texts (Hunt 2019). Ötzi (the 'Iceman') carried a small stash of them, with several in his stomach and one found by his body - they were probably the last thing he ate. Sloes have been interpreted as a kind of prehistoric superfood or medical panacea (Heiss and Oeggl 2009; Hunt 2019) and their thorns have an antiseptic property that rendered them useful as wound stitches in 
the past. As a stored treasure, the eating of a basketful of the blue-black berries may have been more of an honour than a humiliation, to face the trial ahead, reminiscent of the handful of blackberries eaten by Zweeloo Woman or the apple for Kayhausen Boy. As Heaney (1984) puts it in his poem 'Sloe Gin', such fruits were both 'bitter and dependable'.

The undated body of Dätgen Man from Germany (who had eaten a mix of millet and wheat gruel, possibly enriched by venison, shortly before his death) was found $3 \mathrm{~m}$ away from a head (assumed to belong to the same corpse, Gill-Frerking 2014), with its handsome wave of hair also tied in a Suebian knot, suggesting a late Iron Age date (van der Sanden 1996: 113-14). He had been stabbed several times, once in the area of the chest, which penetrated far enough to damage the fifth rib, most likely penetrating the heart. It initially appeared as if multiple assailants were involved, as there was also a wound on his temple and two blows from behind that damaged his third and fourth lumbar vertebrae, as well as damage to his hip and the major limb bones on the right-hand side of the body (van der Sanden 1996: 162). Yet Gill-Frerking (2014: 69) has recently questioned these fractures, suggesting many of them are the result of post-mortem peat compression. What is undisputed is that he was then decapitated: cut marks on the thoracic vertebrae indicate the first blows had happened from the front but the final blow probably came from behind. His genitals also appear to be missing - given the date of discovery (in the mid 1950s) and otherwise good preservation - it suggests that he had been literally emasculated before burial in the peat (Gill-Frerking 2014: 69), around the time of death (Chapman and Gearey 2019:217). The corpse was staked down with heavy timbers in a hollow in the bog (probably an old peat cutting, see Asingh and Lynnerup 2007: 307) in a rite that once more speaks of concerns about his post-mortem animacy. The excessive violence shown here, the multiple stabbing and the likely targeting of his manhood, remind us of the rumoured fate of the licentious tacksman from Lewis (a 'middleman' who arranged the setting and collection of rents for his laird but clearly abused his position by molesting local women, reputedly put to death by a local mob, see Cowie et al. 2011: 25). It is an uncomfortable thought that some of our treasured museum exhibits may be rapists, murderers or criminals, but this was a world without law enforcement, prisons, rehabilitation systems or (for much of the period) even locks. At least some of these bog bodies represent the fatal justice thought fitting to a crime.

Apart from heads, other body parts are known: a leg and foot (showing amputation cut marks) with shoe and woollen 'sock', from Lengener Moor (van der Sanden 1996: 91) and a foot found in a Roman-style shoe at Südmentzhausen (van der Sanden 1996: 79). The nineteenth-century poem 'Die Hand im Moore' commemorates the discovery of an isolated appendage in Germany, well away from any other remains (van der Sanden 1996: 92). Amputation by accident, punishment, conflict or even quasi-medical intervention would all have happened in the past, as would the post-mortem taking of relics: at Cladh Hallan it was the whole 'knee' joint that was sought out and curated. What should one do with such limbs? Detached body parts would have had symbolic meanings lost to us but 
also a disquieting and uncanny force that might have required their individualised 'burial' in a pit (seen extensively in the Wessex storage pit tradition, see Cunliffe 1992; Aldhouse-Green 2002) or as here, in the bog.

\section{The case of Lindow Man}

Lindow Man represents the remains identified as Lindow II, and possibly Lindow IV from Cheshire in the UK. He was reasonably healthy when he died, sometime between the first and second centuries AD (Gowlett 1989; Housley et al. 1995). He had mild osteoarthritis of the thoracic and lower vertebrae, which suggests he played his part in weight-bearing activities and load carrying, leading to the normal wear and tear we would expect of a farming life. His teeth were in excellent condition, perhaps suggesting some privilege certainly in later life (as identified in a number of significant Iron Age chariot burials just to the east of this region, among the so-called 'Arras' culture, see Giles et al. 2020). His nails too were in neat condition, with no heavy scarring or surface damage seen in the comparative analysis of the nails of an agricultural labourer (Stead et al. 1986: 70). Yet he also suffered from a high level of parasitical worm infestation (maw-worm and whipworm), which would have caused abdominal pain, distention, weight loss and potentially some unpleasant complications (Stead et al. 1986). Nonetheless, he had eaten a last barley-based meal, probably a griddle cake (heated to $c .200^{\circ}$, ruling out a gruel or soup), with some spelt and emmer wheat and a few weed species; barley smut again indicated this was a slightly infected stored crop (van der Sanden 1996: 117). The cereal remains were very finely ground, leaving a sandy trace in the blend, and a number of fragments of the outer layers of hazelnuts were also found. Carbonised fragments, animal hair and tissue suggest the addition of some meat, as well as moss leaves perhaps from local drinking water. This was a man who had enjoyed a diverse and tasty last meal of meat, griddle cake and nuts (Stead et al. 1986: 122-3). Among the gut contents were also found pollen grains of mistletoe that may have been ingested from the surface of a berry or breathed in (Stead et al. 1986: 131). Magilton (1995) and Aldhouse-Green (2002: 124) tentatively link this to classical references of Druidic use of mistletoe. Meanwhile, Ross (1986) has drawn an analogy between the charred griddle cake and a Scottish piece of folklore regarding the selection of a symbolic midwinter 'sacrifice', also linking the pollen to Druidic practice, to argue Lindow Man was a ritual prince: 'devoted' to the gods through death (Ross and Robins 1989). (They even bestowed upon him an invented name: 'Lovernius', based on his fox-fur armband still tied around his upper left arm - the same position as Old Croghan Man's armlet). It is unlikely, however, that this small amount of pollen was significant (Stead et al. 1986: 132), merely suggesting he had travelled through woodland on his way to the bog, or ingested water or food upon which the pollen had settled, giving a season of death around late spring/early summer. Alternatively, the low pollen count might suggest he died later in the year, ingesting berries with a low pollen count residing 
in the stigma (Stead et al. 1986: 132): at this level of contamination, it is unlikely to have been used as a hallucinogen or poison, but it may have been used as a medicine for his intestinal cramps. It has been proposed that he was covered in some form of clay-based iron and copper-rich pigment, as was the Lindow III male bog body (Pyatt et al. 1991; Pyatt et al. 1995). There were certainly elevated levels of these minerals in the torso and hands of Lindow III compared with the heel and background peat, which have yet to be adequately explained (Cowell and Craddock 1995: tab. 13). However, Smith (1993) attributes the 'green fluorescence' observed in the body's hair and nails (as well as the fox-fur armband) to the reaction of keratin with the deoxygenated acidic environment of the bog.

Whether Lindow Man was a 'painted' body or not, the blow to the back fractured a left rib and may have brought him to his knees (Stead et al. 1986: 77), where he was hit on the crown and probably rear-occipital region of his head from behind. This consisted of at least one or two massive blows from something like a narrow-bladed and fairly blunt axe, which caused a transverse depressed fracture of the skull and skin wound of $c .35 \mathrm{~mm}$ in length, driving a wedge of bone into the cranial matter (Bourke cited in Stead et al. 1986: 46). A second fracture of the skull was revealed in the occipital bone in the X-ray, which might have been caused by something less sharp, like a cudgel, since it did not cause a penetrating exterior wound (Stead et al. 1986: 78). The force of these blows had led to a clean break of one molar tooth (Stead et al. 1986: 60), stunning him, if not rendering him unconscious. The damage to the brain and internal haemorrhaging mean that these blows alone would have been fatal but not immediate - the slightly swollen wound margins suggest he was still alive at this point (Stead et al. 1986: 77-8). A high cervical spine peri-mortem fracture between $\mathrm{C} 3 / \mathrm{C} 4$ was also observed (Stead et al. 1986: 46, 65, figs 31 and 77), corresponding to the exterior position of a short, fine length of animal sinew, found around the neck. It was interpreted by the team as a ligature, tied with a central knot and two 'stopper knots', which would have needed a small bar or piece of wood to be progressively tightened like a modern tourniquet (West cited in Stead et al. 1986: 78; see Figure 6.8). This is not a classic strangulation; indeed, its purpose may have been to exacerbate the flow of blood as much as progressively cut off circulation or fracture the neck (Budworth et al. cited in Stead et al. 1986: 38-9). (A 'rilled' iron object found close to the head of Lindow I might have fulfilled this function rather well but it came from peat over $200 \mathrm{~m}$ away, see Stead et al. 1986: 39, fig. 13.) That blood flow was initiated, rather like Grauballe Man, when his throat was then cut just above the ligature as the knot was tightened, leaving a $6 \mathrm{~cm}$ long wound - possibly from a stabbing rather than a slashing or cutting gesture (Stead et al. 1986: 79 and fig. 40). In addition to this focus on the head and neck, there is also a suggestion of a stab wound to his right upper chest, which could not be fully confirmed by the analysis due to decomposition in this area (Stead et al. 1986: 80). Severe head wounds, asphyxiation and exsanguination, finished off by a breaking of the neck using the garotte, brought about a 'multiple' death but not the neat three-fold or triple death favoured by those who wanted to see a Celtic ritual exercised upon this bog body (cf. Magilton 1995). 


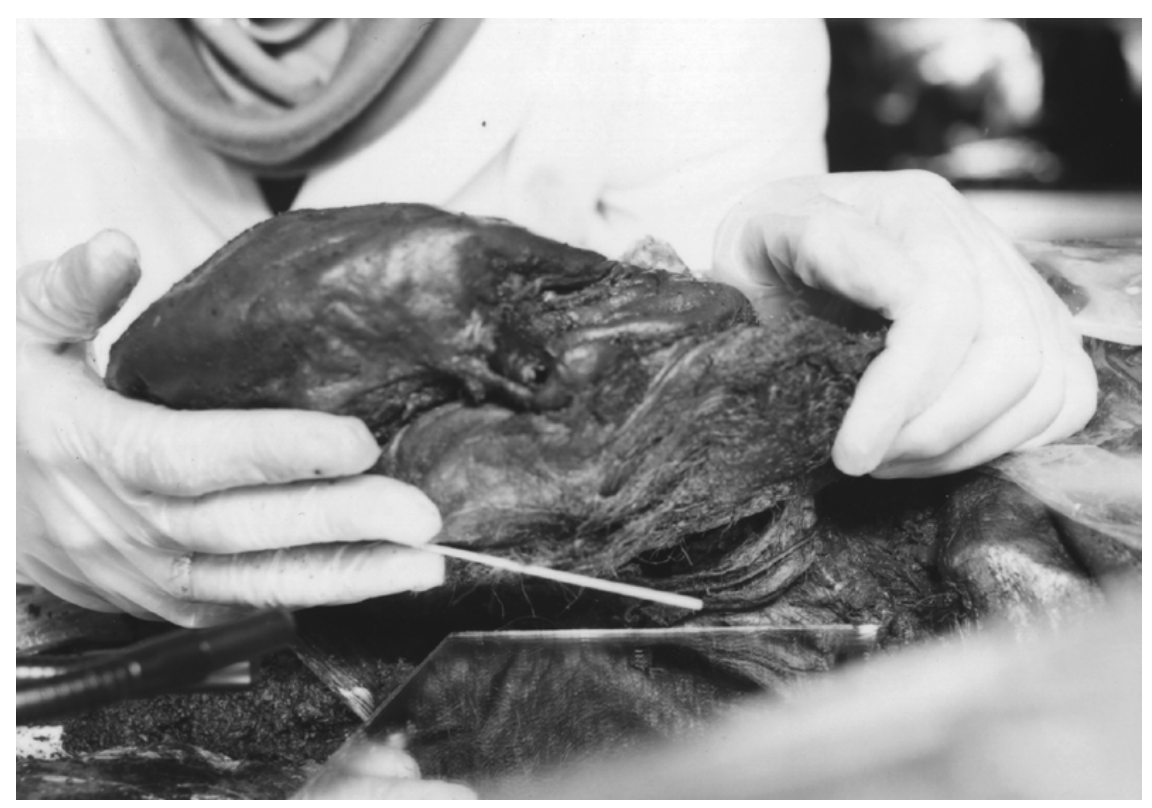

6.8 The ligature and wound to the throat on Lindow Man (@) The Trustees of the British Museum)

In 2004, Ron Hutton (2004b) questioned the circular logic that he felt had fitted Lindow Man too 'neatly' into the pantheon of northern European bog body sacrifices, as promoted by Glob's seminal 1969 volume. He queried the forensic analysis of Iain West (the lead pathologist) in the original monograph, preferring the scepticism of Robert Connolly (the physical anthropologist), who published his own brief assessment of the violence (Connolly 1985) prior to the British Museum volume (Stead et al. 1986). Connolly did not dismiss the skull fractures, but attributed the breaking of the neck not to a garotte but to a final blow on the back of the head/upper neck. He saw the 'ligature' as a 'decorative' necklet for some trinket, failing to find any evidence of stress or trauma on the throat's cartilage; yet at $1.5 \mathrm{~mm}$ diameter and $315 \mathrm{~mm}$ in length, compared with a minimal neck circumference of $255 \mathrm{~mm}$, this must have been a tight fit. As we have seen above, plant tissue or a strip of hide is a more routine fabric for such thongs than the twoply, S-spun animal tissue used here. The rest of the forensic team disagreed with Connolly, pointing out the well-defined abrasive marks on the front and sides of the throat, identical to the position of those on Tolland Man. They did not believe the tightness of the sinew and these indents were the result of putrefactive decomposition, otherwise the area of the beard should have shown a similar signature. Nor was there enough infestation to suggest putrefaction had set in: the body showed every sign of rapid immersion and cessation of decay, and the micro-environment 
of the bog often results in differential preservation between parts of the same body (Stead et al. 1986: 48, 79-80 and fig. 79). Finally, Connolly attributed the neck wound to post-mortem tearing - an important argument given the reassessments of many fractures and flesh tissue discussed above, but none of those reassessments relate to the kind of cut or split seen here. The edge of the wound margin is extraordinarily sharp and neat (Figure 6.8), and there are no other such tears anywhere else on the neck or upper body. In addition, Stead et al. (1986: 79) reported that the thyroid cartilage had been cut, which probably means that the jugular vein itself would have been severed. Connolly did not address this other evidence for violence, as Hutton admits, and both authors gloss over the additional forensic expertise provided by the renowned osteoarchaeologist Don Brothwell (who consulted on many well-preserved human remains) and surgeon Jim Bourke, who mutually authored the final report. Hutton's (2004b) scepticism is also built on the early Roman date for this event, arguing that by this stage 'such [ritual] killings were socially unacceptable and illegal.' Given that we have now have a minimum of three individuals from Lindow Moss (Turner 1995a) and its proximity to the Roman forts of Mamucium (Manchester) and Melandria (Glossop), this again seems a little naive. Both were garrisoned by auxiliaries drawn from Germany and the Netherlands - colonisers for whom violent death and deposition in the local bog was not an unthinkable crime but a well-established cultural practice that (as we have seen) did not cease with their entry into the Roman world. For example, stable isotope analysis of a crania displayed or at least deposited by the south ditch of the Roman fort of Vindolanda reveals this was a local inhabitant from the north-west of Britain, presumably executed and displayed by the military (Buck 2018). A second, Severan era skull - both of which show sharp-force cut marks was found in 2018 near the base of the north ditch (Buck 2018). We will revisit the likelihood of such colonially spurred sacrifice, violence or punitive revenge, in the following chapter. Nonetheless, Hutton (2004a) had a point: the fondness for the trope of ritual sacrifice (Stead et al. 1986: 80) had overridden alternative hypotheses. Lindow Man might have been 'a willing or reluctant human sacrifice, a member of or a stranger to the people who put him in the bog', but he could also be 'a victim of violent crime or an individual executed (justly or not) for an offence' (Stead et al. 1986: 80).

Connolly's (1985: 17) preferred interpretation was that this represented a 'chance wayside killing' of 'a man wearing a necklace'; to underline his point he (or the magazine) commissioned what strikes us as now as a repellant homophobic cartoon of an Iron Age thug confronting an effeminate man who is adorned with 'necklet', handbag and limp hand gesture. The image and its inference would now be regarded as irresponsible scholarship, but it does have much in common with the Nazi use of bog bodies discussed in Chapter 2. To remind ourselves, in 1937 Himmler gave a talk to the SS Luftwaffen in which he claimed: 'This was not a punishment, but simply the termination of an abnormal life' (cited in Taylor 2008: 146). This is not to pretend that persecution did not exist in the past; the Bronze and Iron Age may well have marked the moment when (as discussed 
earlier) quite 'stable, cross-contextual gender patterns snap into clear focus', as Robb and Harris (2018: 141-2) put it. Violence of course still exists in many cultures against lesbian, gay, bisexual, transgender, queer (or questioning) and other (LGBTQ+) individuals. Yet some Iron Age case studies suggest that those who did embody gender fluidity or multiplicity may not have been vilified, but accorded special status (Jordan 2016). We certainly need to think carefully about the risk of mobilising the past in this way, naturalising such a brutal death on the basis of sexual orientation - and this is not something Hutton comments upon.

Briggs (one of the original compilers of the bog body catalogue published in Stead et al. 1986 and revised in Turner and Scaife 1995) became similarly sceptical of the 'sacrifice' theory. He reinterpreted the damage to the Lindow body as the result of someone trying to rescue a struggling or drowned corpse, reducing this to an accidental death (Briggs 1995). He suggested that some of the head trauma and swollen cranial wound margin might have been caused by 'the head protruding from a Sphagnum pool ... and being prodded ... by someone wielding a sharp pointed stock' (Briggs 1995: 174). The differential decay of the hands and presence of some parasitic beetles might be explained, he thought, by such protrusion or exposure on the bog surface (Briggs 1995: 175). He goes on to query many other bog bodies, where the damage to the neck may (along with supposed hanging ropes or strangulation cords and the presence of stakes and hurdles) be the result of using 'hasty makeshifts for rescuing victims of accident', resulting in some unfortunate friction 'burn marks' from trying to drag the body by the head (Briggs 1995: 177). He suggests so-called decapitated heads and other body parts could arise through natural separation, peat compression and convection if not botched rescue and rather than being stripped, the apparent nakedness of many remains might be explained through struggle and loss of garments in the water. Briggs (1995: 178 and 181) questions the published 'execution' methods, seeing them as anachronistic for the Iron Age (perhaps forgetting or ignorant of the revised early Roman date) and muses that no self-respecting executioner would put himself at such jeopardy by dragging a body (dead or alive) out into such a dangerous locale. Many bog bodies, he contends, 'quite definitely fell, some appear to have been mugged and were therefore probably pushed' (Briggs 1995: 182), returning his own 'open verdict' on Lindow Man's demise.

In direct response to Hutton, but also addressing Connolly and Briggs's concerns, the British Museum curator of the Iron Age at the time, J. D. Hill (2004a, 2004b), patiently reiterated contextual and forensic details for a premeditated stripping, preparation and sustained attack upon the individual. He pointed to the fact that whether Lindow Man lived in a pre- or post-conflict generation, relations between the Roman forces and the local communities were probably not peaceable. Hill (2004a, 2004b) thus argued that the notion of planned and in performance terms ritualised killing (rather than pure sacrifice, an important distinction) should be seriously borne in mind. What we can say with certainty, building on the landscape work of Chapman (2015; see also Chapter 4) is that Lindow Man was brought to the furthest locale from the shore, at the deepest area of the bog, 
around the time of his brutal death. From the vital reaction to his wounds, the lack of sustained insect infestation and risk of carrying a 'dead weight' out into the bog, we can propose that he walked out on to the bog. Given the sequence of injuries, it is unlikely that this was a protracted affair: we seem to be looking at a small cohort tasked with taking his life, using multiple methods to 'finish it' swiftly but messily - a bit of a bloody frenzy. This does not help us discern the difference between ritual killing for sacrifice, the swift 'assisted' death of a self-sacrifice or killing for punishment or revenge, but the evidence does point to an aspect of preparation, choice of locale and multiple participants. Essentially, what Hutton called for was an honest plurality of interpretations - this book finds no disagreement with that exhortation. Ritualised killing (as proposed by Hill) - whatever the motive - is an apposite concept to describe this event.

\section{Violence in the Iron Age and early Roman world}

The scepticism of Briggs, Connolly and Hutton is understandable given the infamy of the 'bog body', the spurious 'Celtic' mythology woven around these remains and the notoriety, contention and debate surrounding their display (Giles 2009; Sanders 2009). Yet their apparent reluctance to accept shocking levels of interpersonal violence in later prehistory is misplaced if not surprising (see James 2007; Redfern 2016; Smith 2017). In this section, I want to put the bog bodies in context by using evidence from Iron Age sites within the UK and the near Continent, moving from a few dryland examples to wetter case studies. Like the bog bodies, these tend to be non-normative mortuary rites and some, but not all, show evidence of violence.

In the hillfort of Danebury, a variety of complete, partial and fragmentary human remains were found in disused grain storage pits (Cunliffe 1995; Booth and Madgwick 2016). They show a disproportionate degree of violence compared with a normal population (Sharples 2010; Cunliffe et al. 2015), largely meted out to adult males, including sharp-force wounds (from picks, axes and swords), knife wounds, spear-blade and spear-shaft injuries and blunt-force trauma. Deposition 11 , for example, had a peri-mortem spear-blade puncture wound straight through the frontal bone and a depressed fracture (possibly the spear shaft) in the top of the cranium, as well as a grazing, glancing blow that caused a hairline fracture (Cunliffe 1984: 471, fig. 8.11). Some individuals had survived this inter- or intragroup violence (deposition 50, with a sword cut to the head and a fractured rib that may or may not be accidental) but most did not (including deposition 11, see Cunliffe and Poole 1991: 428). Severed yet fleshed heads (usually adult male) were sometimes curated, perhaps displayed, so that mandibles became detached from the crania (such as in pit 448 and 639, see Craig et al. 2005). A 'nest' of such skulls was found in pit 2509 (Cunliffe and Poole 1991: fig. 8.2) while two adult male crania, both bearing massive sword injuries, were found together in deposition 196a/b (Cunliffe and Poole 1991: fig. 8.4). When fleshed, the skulls 
would have borne an uncanny resemblance to the Osterby or Stidsholt heads, while their post-cranial remains would have resembled the torso of Old Croghan Man. Butchered pelvic fragments were also found, such as deposition 47 in pit 1020 (a young male, hacked from the legs by chopping through the heads of the femurs and the sacral vertebrae with a sword) and deposition 94, pit 900 (another young male consisting of a pelvic girdle with five lumbar vertebrae still in articulation). Decapitated and armless skeletons were also found (depositions 3 and 10: the latter an adult female from whose spinal column and sacrum had been removed and placed at her legs, see Cunliffe and Poole 1991). Yet although perimortem violence was high, the apparent 'butchery' of this dismemberment was carried out after death, as with Old Croghan Man and Clonycavan Man (Booth and Madgwick 2016). Adult men and women dying in their prime may still represent 'normal' deaths from diseases or infections that left no skeletal trace and were excarnated to allow partial decay before selective retrieval and post-mortem manipulation, followed by deposition of some body parts (Booth and Madgwick 2016). The focus on the head (which will be further discussed in the following chapter) and elements such as pelvic girdles are interpreted by Cunliffe (1992) as part of a range of highly symbolic, propitiatory offerings (human, animal and material) to the gods for the safe storage of grain. Sharples (2010) does not dismiss this idea completely but points to the relatively high proportion of violent death relating to adults, especially but not exclusively males. He argues that these were socially marginal figures, cut out from a close-knit community or ripped from a rival group: selected for violent death as part of small-scale conflicts (such as the five individuals from a range of contexts who may have died in a specific event around the late fourth or early second century BC, see Cunliffe et al. 2015) or more individualised sacrifices or killings that bound the hillfort together (Sharples 2010). In such a tightly knit yet pressurised community, he argues that domestic and neighbourly violence may have been elevated, stoked by fears of malign, supernatural activity: what we might loosely describe as witchcraft. The movement of stock around an increasingly patrolled landscape (indicated in stable isotope analysis by Hamilton et al. 2019) no doubt created other moments of inter-group friction and violence. Like the staked bog bodies, some pit 'burials' were tied up (deposition 22 in pit 497: an adult woman with her hands 'crossed' as if tied), 'stoned' or covered over by slingshots (pit 935), and weighted down with flint or chalk blocks (see Cunliffe 1993: 12-13). Some were prone: interred face down (e.g. deposition 24) or thrust head first into the pit (deposition 16, pit 383, see Cunliffe and Poole 1991). Like the Cladh Hallan composite bodies, others were apparently curated in a protected decay environment or 'sheltered exposure': covered over from vermin, scavengers and weather while they rotted to a point where post-mortem manipulation or tight rewrapping (as at the nearby Suddern Farm) could take place (Booth and Madgwick 2016). The use of cold, subterranean storage repositories to create a 'useful' corpse or facilitate and control their post-mortem career (as ancestor, enemy, witch or revenant) seems uncannily similar to the powers attributed to the bog. 
In the ditch of Sutton Common, a so-called 'marsh fort' set in the fen carr of South Yorkshire (not far from Hatfield Moss and Thorne Moor) a pair of 'defended' enclosures dating to $c .372-350 \mathrm{cal} \mathrm{BC}$ were constructed in a landscape of change where grazing was opened up and local woodland felled. The site was primarily been used for large-scale grain storage and the eastern entranceway had at some point been heavily burned, perhaps in a raid (van der Noort et al. 2007). In its northern terminal, two sets of human remains were found: both male, aged between twenty-five and thirty-five years. One (A) was a cranium with mandible fragments, suggesting that this had been a fleshed head. The other (B) consisted of the cranial fragments and the atlas (but no other cervical vertebrae and no mandible) suggesting that the cranium and some attached fleshy neck tissue were deposited into the watery ditch (van der Noort et al. 2007: 139). They could have been 'severed' heads taken as trophies or merely partially decayed remains from mortuary sites; either way, their deposition created a morbid yet hidden presence, watching over the mire of Shirley Pool. 'Fleshed heads' were more prominently on display at the site of the Glastonbury Lake Village (Somerset), with one showing peri-mortem sword cuts and damage to the foramen magnum suggesting it had been paraded on a stake or spear shaft (Coles and Minnit 1995: 170-4). At Heslington East near York, the head of a male aged between twenty-six and forty-five was deposited in a pit near a spring site that would have been essential to both seasonal and diurnal movements of stock on and off the dryland ridge and wetter pasture (O'Connor et al. 2011: 1643). The cranium and mandible appear to have been fleshed at the time, deposited 'face down' in the waterlogged pit sometime between 673 and 482 cal BC, preserving a shrunken mass of brain tissue in the process. The head had been traumatically decapitated, peri-mortem, between cervical vertebrae (CV) two and three, with a sharpbladed weapon. This was followed soon after by nine 'sawing' cut marks from a knife used from the front of the corpse, indicative of 'almost surgical', 'careful and deliberate dismemberment' of head from torso (O'Connor et al. 2011: 1645 and 1648). Putrefaction was halted, suggesting the head had effectively been curated in a cold, slightly acidic, fine-grained, wet sediment. Was this a revered 'cowey' or 'bullocky' (as stockmen were later known in this region) protecting his own even after his death, or put to death and used to pollute the spring? The severing of the head, humiliatingly placed face down in the wet mud, suggests it could equally be a rival or enemy, an executed cattle raider or water thief.

At the site of Stanwick in northern Britain, another severed, fleshed head was found in the wet ditch of the north-west entranceway. The victim received three blows from a sword or sharp axe, before final decapitation (Wheeler 1954: 54). Wheeler (1954) considered the head to have been a trophy on the oppida's gateway, later 'cut down' and thrown in the watery ditch by Roman forces. Yet Haselgrove (2016: 440) notes that it was found metres away from an impressive Iron Age sword and a length of rope that might mutually represent a deliberate watery deposit, potentially a 'multiple' death involving hanging if not binding. They caution that 'violent death does not necessarily make the man a stranger' (Haselgrove 
2016: 442): this 'royal' locale, related to the figure of Queen Cartimandua, was the site of more than one betrayal and broken alliance, stoked by the rewards and dangers of working with the Romans. Meanwhile, the secluded but dramatic site of Sculptor's Cave, Covesea in Scotland (used for mortuary deposits in the Bronze Age), seems to have been repurposed as an execution site in the late Iron Age/ Roman era (Armit et al. 2011). A mix of sexes and ages represented here in the human remains, coupled with evidence for an orchestrated bodily performance with victims forced to kneel and yield to decapitation from behind - suggests the sanctioned dispatch of hostages: perhaps a noble family or lineage, wiped out during turbulent political times (Armit et al. 2011: 275; Giles 2015).

Keepsakes, apotropaic amulets and curios were made out of other human remains. At Ham Hill (Cunliffe 1984: 455) and Hunsbury hillforts (Lally 2008), the wetland votive deposition site of Fiskerton (Field and Parker Pearson 2003) and Cnip wheelhouse (Armit and Tucker 2010) cranial fragments were drilled or pierced post-mortem for hanging and display. Some like Cnip were clearly 'found ancestors' dating to a few hundred years before their interment; others may have more been recent figures, whose remains served as mnemonics for personal relations. Yet some were 'fresher' victims cleaned and kept as polished, portable trophies. At the hillfort of South Cadbury in Somerset, in situ killing and destruction is complemented by episodes of selective collection, processing and 'display' of the dead (and their weaponry, see Barret et al. 2000: 115). Two separate phases of conflagration at the entranceways were linked with a number of bodies who had died violently, yet some beheaded and burned skulls seem to be the result of more purposeful curation and cleaning for display. Damaged weapons and martial kit in the west guard chamber suggests the collection of material trophies, complementing the human remains. At Gussage All Saints (Dorset) a fragment of adult femur was 'decorated' with two rough dotted circles composed of small, adjacent pits (Redfern 2008: fig. 7), while a young adult cranial fragment from Maiden Castle was pierced or drilled with a hole (Redfern 2008: fig. 9). Meanwhile, at Billingborough in Lincolnshire, an Iron Age settlement contained fragments of cut and polished cranial fragments, especially vaults, sometimes pierced to aid suspension or to make cranial 'bowls' (Chowne et al. 2001: 77). For example, no. 5 was sawn, polished and pierced (Chowne et al. 2001: 77).

The above sites differ in scale to the Continental complexes of La Tène, Cornaux-les-Sauges and Marin-Epagnier in Switzerland, or Ribemont-sur-Ancre and Entremont in France (see discussion in Aldhouse-Green 2002), or indeed the later weapons deposits of Denmark (Hjortspring, Vimose, Alken Enge and Illerup). Yet the notion of the gathering of deliberately ruined weaponry and body parts for public display and deposition (often in or near watery contexts) is a theme found across mid to late Iron Age northern Europe. At a large or small scale, they tell us that human remains were part of the material embodiment of lethal power that was increasingly used in display, performance or deposition: exercising humiliation, celebrating victory, collecting, cleansing and offering up ruined bodies as well as blades. 
I want to end this brief survey with a study of the terp region of the Netherlands by Annet Nieuwhof (2015). On this artificially reclaimed and built-up landscape, located near to both the coast and peaty wetlands, she demonstrates an extraordinary array of Iron Age mortuary practices. There are the titular 'eight human skulls in a dung heap', argued to be the end-point curation of valuable, excarnated skulls, kept in a material redolent of the hearth, warmth, fertility and thus 'good fortune' (Nieuwhof 2015: 140). To this phenomenon she is able to add formal inhumations, isolated excarnated bones (gnawed and weathered, some defleshed), rare cremations and a suite of human remains modified to make cranial bowls, pierced roundels and a handle. Not far from the settlements and burials on the terp itself, the peat has yielded what we would classify as 'bog bodies. Violence at the point of death and post-mortem processing is represented across these remains, such that with the highly modified and curated body parts it is impossible to distinguish between 'trophy heads' and the 'curated skulls of venerated forebears' (Armit 2012b): the reviled and the revered. Nieuwhof's approach is not to judge their identity and relationship to the living, but to observe the diversity of rites and contrastive locales of deposition within close proximity.

This selective review from a range of sites from Iron Age Britain and the near Continent situates the British bog bodies and heads - the individuals from Lindow, Ashton Man, the women from Pilling Moss and Red Moss - into a world of endemic conflict. Their injuries and fate differ little from Stanwick Man, the Heslington head or the Covesea victims. The wounds on such skeletonised remains are a pale shadow of the full suite of trauma suffered by some of these people as they died and we are largely missing the hangings, strangulations, pierced major organs and flesh wounds that the bog bodies allow us to 'see'. Perhaps this is why we are so perturbed by the apparent 'overkill' meted out to the bog victims, when its visibility is merely an accident of preservation. At one level, the purpose of this section is to debunk the 'specialness' of the bog bodies, and propose that the moss and the mire are merely the appropriate place to dispose of such remains for those living in its shadow: in Wessex it is a storage pit, in Yorkshire a wet ditch or hollow and in Scotland it could be a cave. Whatever the circumstance or motivation, the bloody matter of a killing needed careful handling: it was the very stuff of life. We therefore need to see the bogs within a wider suite of powerful locales where subterranean forces (particularly those linked to water) could help mediate practices that spilled life over into death (Bradley 2017). It is to the performative dimension of those actions that the next section turns.

\section{How we die: performing death in the Iron Age}

Much of the violence done to bog bodies, whether it was carried out upon a living being or their remains, was highly performative. For example, we can interpret the 'stripping' of clothing as an ante-mortem act of humiliation, rendering them vulnerable, shamed. Yet nakedness on the cusp of death might alternatively 
embody heroic nudity, as in the Archaic period in Greece. In Histories, Polybius (cited in Shuckburgh 1962: 2: 28) tells us that the several Celtic barbarian mercenaries fought naked in the battle of Telamon $225 \mathrm{BC}$, a custom also reported among the Gauls by Diodorus Siculus in Bibliotheca Historia (Oldfather 1933: V, 29: 2 and 30: 3) as the embodiment of boldness and bravery. We should also remember folkloric attitudes to the apotropaic power of cloth associated with sudden death or mysterious preservation - the taking of textile scraps from Lady Moira's Drumkeeragh bog body and the Berrybrush 'suicide' victim. If some of the bog people were sanctified towards death, about to enter the divine, then perhaps through spiritual contagion their clothes now had a new value, a protective power. These textiles may have been deliberately taken (still warm, from the living body poised on the cusp of death) to enter a new life used perhaps in acts of memory, apotropaism, medicinal cures or even new inaugurations.

Beyond the symbolic violence of stripping or declothing, rarely do we see the use of a single fatal wound and more often, multiple methods and implements were used. Much of this is palpably different to the techniques used to dispatch and butcher animals in the Iron Age; maiming, torture and violent humiliation such as the stripping of clothes or cutting of hair, suffocation, garrotting, hanging or stabbing are all peculiarly human ways to die. We can tentatively note a difference between the opportunistic, random and pragmatic frenzy of conflict (doing whatever was needed to finish someone off, often ending with humiliating disfigurement or trophy taking), and the more controlled, highly performative spectacle of an execution or a sacrifice that may target symbolically loaded areas of the body. The latter two are often indiscernible, and execution need not involve criminality it can be the sanctioned means of making a sacrifice (Bo Jensen pers. comm.) The staging of these planned modes of death constructed a ritualised trajectory, a parabola of staggered violence. They required setting, timing and sequence: the 'hitting' of pre-planned marks punctuated by moments of devastating rupture, then stillness (see Pearson and Shanks 2001). Such violence was necessarily improvised: a struggle between perpetrator and victim. As Larson (2014: 83) puts it: 'everyone, even the victim, must play their part'. Their mutual demeanour was an unknown quantity: how much humiliation or pain was inflicted, how and by whom, and whether this was meant to be endured or end swiftly. We do not know the size of the audience - the use of the bog suggests that something that began publicly on dry land might end more privately on the moss at the hands of a small group. It involved a journey: a temporal rhythm fraught with extreme stress and fear. The scale and character of most of the deaths in the bog fit well with the notion of 'participatory violence' discussed by Aldhouse-Green (2002). This concept can apply to small mob killings, 'rough' justice or sanctioned judicial acts, like the 'firing squad' whose bullets mutually penetrate the captive or gang violence where no one hand deals the final blow. Yet it has most often been related in bog body studies to Girard's concept of the cathartic power of a communal act of 'scapegoating' (Sitch 2009): a sacrifice serving to protect the wider community from its own violent tendencies by exteriorising and freighting the victim with 
its fears, urges or ills (Aldhouse-Green 2016: 175). Girard (1977) argued that this phenomenon was most often seen at times of crisis where its effectiveness was magnified by collective action. Aldhouse-Green (2002) argues that such sacrifices also depended on visceral performance, the shedding of blood, seizing of breath or tearing destructive frenzy, which people believed put them in touch with the divine. The 'taking' of such anima (as the Classical world defined it) is similar to Bloch's concept of the release and capturing of 'transcendental vitality' (Bloch 1982). Bloch suggests that this is managed through moments of violence that sever the victim from the everyday (perhaps embodied in the bog bodies through stripping, cutting of hair, binding or hobbling and taking out on to the bog) before a second more dramatic violence that harnesses a new, creative vitality: allowing the participants to 'return' to everyday life but leaving them tainted or glowing with this transcendental aura (Bloch 1992, discussed in Ralph 2013: 7-8). This is not just sanctioned but 'sanctified violence' (Ralph 2013). In contrast to Fontijn's work on deposition, sacrifice here is seen as 'a means to an end rather than an end in itself' (Aldhouse-Green 2002: 20): an exchange designed to reap benefits, rooted in commensal, violent action. One of the outcomes of this then, is the renewing of the forces of life and fertility that Glob ([1969] 1971) argued lay at the heart of the deaths of both Tollund Man and Grauballe Man. Even if it does not explain all bog bodies, it is an important corollary to the anti-ritual and anti-sacrificial stances of Briggs and Hutton.

Whether we believe Lindow Man was a sacrifice or an execution, we can helpfully focus - like Fontijn (2020) - on the dramaturgy of death and deposition. Such dramas were designed to terrify, appal, demean and sometimes, obliterate the performance of killing is, after all, one of the most powerful psychological weapons of conflict (Hughes 2011). Importantly, the fact that the bog bodies sank from view puts them in a different category from those remains manipulated through display or curation (such as the gathered up remains from Alken Enge). Following deposition, they were materially intangible - their force lay in the imagined, threatened and remembered fears of witnesses and participants (James 2013: 103).

Violence here is conceptualised not as purely destructive but constructive (Ralph 2013: 7): in the Iron Age it patrolled boundaries, reinforced cultural rules, punished transgressions and offered revenge. Bellicosity was a trope of power (Harrell 2012) and violence worked because of its 'eruptive possibility' (Whitehead 2004: 18). In the Iron Age and Roman period, it was not an aberration: James (2013) encourages us to rethink of 'the calculated use of injurious force' as a kind of 'instrumental violence' not an impulsive or pathological one. It was part of how people 'became' as well as how they were 'undone'. Violence revivified, motivated and inflamed just as it also, at times, made an end of things. This is not to negate the damage wrought by violence but rather, to recognise that it was a productive tool with which to order the world; a strategy of legitimation that categorised some as inhuman, relegating their deaths to unmournable, 'ungrievable' lives (as Butler (2010) has recently put it). If at least some of the bog bodies do indeed represent sacrifices, it presumably 
also offered hope to the perpetrators that their gesture would in some way be reciprocated. Intervention, assistance, restitution or good fortune might follow. What was required then was a 'good' performance that was fitting and just: evaluated not merely by other people (die he/she 'die well' or 'suffer enough'?) but judged by the spiritual world to have intervened appropriately with the forces of life and death (see Giles 2015). Such a performance and the affects it wrought embody the ambiguity that Heaney (1999: 4) captures in poetry, where these deaths lie somewhere 'between beauty and atrocity'. Those that managed this feat earned renown for a prowess that was not simply martial but supernatural (Aldhouse-Green 2002: 197). As unpleasant as it is to contemplate, the 'poetics' as much as the politics are crucial to understanding the particular purpose of violence (Whitehead 2004).

What were such deaths like then, both for the victim and perpetrator? Chapman and Geary (2019) have recently contemplated this from the perspective of an 'archaeology of pain' based on the intensity and duration of the victim's suffering. In contrast, this chapter has sought to understand the full biography of the individual before such events unfolded, and my approach draws instead upon the extraordinary study entitled How We Die by medical expert Sherwin Nuland (1993). Drowning, whether by accident, suicide or deliberate force amounts to a form of asphyxia where water fills the airways and passes down into the lungs. It is not a particularly quick death - taking perhaps two to three minutes before decreasing oxygen levels in the blood relax the spasms of the larynx, leading to a 'terminal gasp phase' (Nuland 1993: 161). Hanging is also neither a swift nor a pleasant death, relying on the victim's own body weight (or bystander's assistance) to hasten the obstruction of the airway to cause death through asphyxia. According to van der Sanden (1996: 155), this can take up to twenty minutes though unconsciousness may be immediate. The transfigurative effect of such a slow death upon the face, seen also in strangulation, can be appalling (Nuland 1993: 160). Given the serenity of Tolland Man's expression, his death was probably precipitated by the skilfully positioned knot that fractured and dislocated the spinal column at the base of his skull, causing immediate shock, paralysis of respiration and a swifter death (Nuland 1993: 160). Decapitation, meanwhile, has the illusion of 'a brutal but effective' death, intensely painful but short-lived. As Larson (2014: 13-14) notes, for the onlookers it 'draws its cultural power from its sheer velocity ... death is presented as instantaneous'. Fatal haemorrhaging from blunt- or sharpforce trauma, known as exsanguination, often begins with hyperventilation: the body's fight to compensate for the loss of oxygen in the blood. Eventually the brain will cease to function; unconsciousness follows but the 'lower' part of the brain will try to continue respiration, before fibrillation (cardiac arrest) precipitates the agonal breathing that heralds clinical death (Nuland 1993: 124-9). Yet Nuland (1993: 129) reports that in such cases of very rapid bleeding out, victims often appear not to register terror or shock as much as surprise, even release, which he attributes to the release of endorphins that create a kind of stupor or insulating aura (Nuland 1993: 133-4). I have summarised 'ways of dying' that relate most closely to the bog bodies not to dwell on their horror but to think about the temporal 
sequence, visceral effect and spectacle created through these modes of killing. The experience was designed to be theatrical, morbidly thrilling, coruscating even in the squeezing, wringing, wounding bloodshed it wrought. Yet Nuland's insights suggest that for many it was fast, with unconsciousness marking the beginning of their demise. Perhaps this helped render them pliant during the rest of their ideal but there is certainly a sense of the hastening of death in many cases. This is not, however, to diminish the minutes, hours, days even, during which a victim may have been intimidated, abused, humiliated or tortured. The rare 'slave' chains, anklets and manacles from sites like Llyn Cerrig Bach or Bigbury hillfort (made of solid forged iron - a precious commodity) suggests that some of these people may have been important hostages kept for a time, mindful of their final fate. Diodorus Siculus (cited in Oldfather 1933: V, 32.5-6) reports upon this 'outlandish impiety ... with respect to their sacrifices, for their criminals they keep prisoner for five years and then impale them in honour of the gods, dedicating them together with many other offerings of first fruits'. Randsborg (2015: 19) contextualises this growth in hostage taking (for surety) and killing (for revenge) in the political cauldron of tribal rivalry, wavering imperial alliances and indigenous betrayals that characterised Rome's move into northern Europe.

\section{Precarious lives or honourable ends: the identity of the victims}

As the previous section implies, there were good ways to die in the Iron Age (sudden, unexpected, preferably in one's sleep) and bad ways to die (protracted, painful, enervating, humiliating, robbing people of their personality and dignity). So who were these 'victims' and does this alter how we see their deaths? Using both textual and archaeological sources, Aldhouse-Green (2002: 139-60) describes the different categories typically selected for sacrifice or ritual killing: prisoners, enemy captives, liminal or outsider figures and slaves (often selected as acceptable 'scapegoats'), youths and children (thought to be particularly rich or abundant in purity or fertility), as well as the 'afflicted', 'marked out' by deformity, debilitating injury or disease. Van der Sanden (1996: 178) cites the classical texts on both prisoners of war, offenders/criminals and children, mentioning an instance of intended child sacrifice, chosen merely 'by lot' in early medieval Frisia, which an early Bishop, Wulfrin, averts through a miracle. Lottery too, of a kind, is mentioned by Strabo in relation to female priestesses from the Loire island sanctuary (in Iron Age France) from whose midst a sacrifice had to be found (cited in Aldhouse-Green 2016: 146-7). She was identified by the 'dropping' of a bundle of reeds intended to reroof the sanctuary: a 'drawing of the short straw' that actually seems more strategically designed - 'it always happens that someone pushes against the woman who is destined to suffer this fate', Strabo notes (Geography 4: 4.5-6 cited in Aldhouse-Green 2016: 147). Taylor (2002), like Aldhouse-Green, suggests that many bog bodies fit the concepts of the 'other', which allowed them to be sanctioned or licensed for death when it was required. More recent scholars 
have further probed this uncomfortable issue of necropolitics: who was chosen to die and why (Fredengren and Löfqvist 2015; Fredengren 2018). They have investigated the detailed osteobiography of bog bodies to show that aspects of disadvantage, misfortune or stigmatisation are common. Many of the Swedish bog skeletons at the heart of their study show evidence of repeated infection, malnourishment, wounding or disability, suggesting they may have been perceived as unable to fulfil what was expected of a 'good' and useful life (especially, perhaps, for men). In other words, Fredengren (2018) argues, they were already living precarious lives before their demise. She draws here on Braidotti's (2013) work on people who qualify for protection and are allowed to thrive, versus those that are left out and consigned to different fates. To cite Judith Butler (2010) again, we thus need to ask which lives were not just 'grievable' but also expendable? Importantly, this thesis notes these were not simply 'natural victims'. It was the ongoing marginalisation and vilification shown to some people that precipitated a slide or gradual descent; a longitudinal cultural 'othering' through which such bodies could then satisfy the 'sacrificial logic' of their communities, consigning their life to death.

How generalisable is this model? Outside of Sweden, we do have examples of bog bodies who seem to have had particularly challenging and stressful lives. Windeby Boy and Aschbroeken Man had both experienced periods of nutritional stress in their lives, leaving their trace in Harris lines on the bones and enamel hypoplastics on dentition (van der Sanden 1996: 112). Aschbroeken Man had incipient lipping of his lumbar vertebrae from aging, as well as a healed fracture to his right humerus that had set out of place (van der Sanden 1996: 138). Elling Woman suffered from osteoporosis at the fairly young age of thirty (van der Sanden 1996: 141) and a disadvantaged diet would have exacerbated this condition. Bellevue Skov Woman had a small osteoma - a benign but uncomfortable tumour - on the right tibia (Ravn 2011: 85). Yet all of these conditions might be expected in an average Iron Age farming community. Rarer conditions and evidence for medical intervention are more telling. One of the two bog skeletons from Døringe in Denmark had a severely foreshortened right humerus and a split in his thoracic vertebrae indicative of spina bifida; his skull showed evidence of at least one trepanning from which he had recovered (van der Sanden 1996: 142). He was found close to another man who also had a suspicious cavity in the skull but this had not penetrated completely and had healed; a foreshortening of his right humerus and deformation at the femoral head was probably caused by a fracture or dislocation during infancy that never healed properly (van der Sanden 1996: 142). Here we have two males, surviving into their adult years but clearly unable to perform the kind of active life perhaps expected or hoped of them. We have to consider whether their parallel treatment amounts to a stigmatisation of people with a disability, with potentially fatal consequences. The Gadevang bog body had been subject to a trepanation, perhaps suggesting concern with cranial pressure, pain or behavioural change (Ravn 2011: 85). As discussed above, Zweeloo Woman had an irregular gait, with shorted limbs attributed to dyschondrosteosis (van der Sanden 1996: 141; Bianucci et al. 2012). 
It is surely not controversial to point to the higher risks of illness and violence faced by those on the bottom rungs of society, nor to suggest that weakness or impairment might have become prey to prejudice and persecution. Yet we generally lack the large-scale Iron Age population data to evaluate how common such infections, disease and injuries were. Where it does exist, as for the Arras culture of East Yorkshire, it shows that a considerable number of people suffered from childhood malnutrition, minor fractures, infections and small disabilities - a limp, repeated infections, a withered limb or abscess were not uncommon (Giles 2012: ch. 5). Only a few of the bog bodies (Yde Girl's scoliosis, Lindow III's vestigial thumb, Zweeloo's foreshortened limbs) exhibit the kinds of extraordinary physical difference that occupy the pages of more popular monographs on the topic. Psychological abnormalities were probably of equal if not more pressing concern, though we can only infer this archaeologically where there was a physical cause or intervention such as the above trepanning that can be observed. In conclusion, while some bog body victims fulfil the notion of the 'precarious' or 'stigmatised' body, others bearing these symptoms survived without being hounded into the bog or set up as scapegoats (Ravn 2010). Indeed, these marginal figures are complemented by individuals drawn from the opposite end of society: physically impressive, well-fed, well-dressed people who appear to have avoided an arduous agricultural life. For example, Hall described Old Croghan Man as 'the golden boy of his tribe ... even in death, he oozes confidence, status, presence' (cited in Grice 2006: 20). Apart from the common curse of intestinal parasites, they seem to represent the very best a community could offer. Some were well travelled, skilled and presumably, well connected. They still ended up in the bog. These figures must also be counted.

Perhaps we need to approach the bog body phenomenon from a slightly different angle, suggested from Chapter 5's study of what else went into the moss and the mire: how Iron Age communities managed the 'end' of things. During later prehistory, particular kinds of people might have sought a certain kind - or time - of death. Treherne (1995: 61) argues that Bronze Age warrior figures not only strove for a 'beautiful' way of life but a particular 'death style - a socially prescribed way of expiring', preferably at the height of their prowess and in conflict: meeting death well. While the notion of a pan-northern European 'warrior identity' can and should be deconstructed (Brück in Frieman et al. 2016), we should not demean the distinctive practices, mundane as well as spectacular, through which armed figures shaped their force while alive and renown in death (see Giles in Frieman et al. 2016). Among the Dinka of Southern Sudan, for example, the 'Spearmaster' must not let Death take him; he must craft his own end, 'leaping' into death to seize a final victory (Lienhardt 1961). Above, the case of the Huron captive was used to make some sense of the suffering meted out to robust male bog bodies. Gaulish captives like Vercingetorix had to 'die well' in the Roman world, at the end of a tortuous imprisonment of six years, waiting for the auspicious moment of the Gallic triumph in 46 BC (Östenberg 2009). This was to be borne, as part of one's mortal fate, even in defeat - and if there was an afterlife or supernatural realm, then this 
was merely a painful but assured and honourable entry into it. Self-sacrifice offers another explanation then, for some of the bog bodies (see Giles 2009): giving themselves up perhaps not just as a gift but as an emissary during a time of crisis or to be transformed into a powerful supernatural agent to advise and intervene from beyond the grave (Williams 2003). This transformation then, may have held out the promise not just of post-mortem renown but possibly of conjoining with the divine. The exchange of life force achieved through this voluntary violent death may have been believed to be essential to renew the power or fortunes of their own community. In the Yoruba play Death and the King's Horseman, Wole Soyinka (1975) conjures how British colonial authorities sought to prevent what they saw as a 'suicide': intervening in the duty of the king's right-hand man to offer himself, his horse and dog to guide their master into the afterlife. The dawn comes and the auspicious moment passes without sacrifice, irretrievably disrupting the circle of honour, potent vitality and procreative force that his death should have wrought.

In a community with a defined concept of human offering (whether we use the word sacrifice or not) someone needed to die. This creates a completely different ontology to our own. One of the keynote addresses to the 'Alken Enge' conference in 2016 was given by Rane Willerslev in the atmospheric hall of Moesgaard Museum, close to where Grauballe Man lay. Willerslev, a renowned anthropologist of the Chukchi hunter-gatherer communities in Siberia, challenged the audience to think critically about what made a sacrifice. Talking movingly of the people he had studied, who faced the kinds of arduous environment and challenging seasonal movement we can only imagine, he surveyed the audience and said simply: 'no one there needs to die of old age'. He went on to explain the Chukchi's strong tradition of human (and other) sacrifice, and how elderly people reaching the end of their endurance, facing great pain or terminal illness, begin to commune with their forebears in such a way that it 'licensed' their kin to take this as a sign to end their lives. Such a 'voluntary death' as Willerslev put it, appeased and pleased the gods with an offering of a life well lived. In an Iron Age world devoid of sedatives and painkillers, a sudden yet excruciating demise might have been preferable to lingering suffering, while 'assisted suicide', 'mercy killing' or 'euthanasia' may all have been used as strategies to hasten a life that was no longer liveable or a death that was believed to be inevitable. We are suddenly, uncomfortably close to Heaney's (1972) 'old man-killing parishes'. Willerslev's lesson (I think) was to warn us that some bog bodies may have been caught up in a sacrificial ideology that (whether deliberately or not) helped deal with the one certain end of human existence, often cruel: snatching from it a swift end and a regenerative, commensal power.

\section{Conclusion}

This chapter has explored the lives and deaths of numerous bog bodies, critically evaluating different interpretations of this phenomenon. As Glob ([1969] 1971: 105) sensibly suggests in his original monograph: 'We cannot view as one 
uniform phenomenon the many bog people from this long span of time. Both Burmeister $(2007,2013)$ and Joy (2009) reinforce this point, arguing we should be proposing a plurality of explanations and dealing with examples on a caseby-case basis. Standing back from the overview provided by van der Sanden, enriched here by a synthesis of new studies, we can see some general historical patterns emerge from the data. Earlier prehistoric bog bodies show few signs of violence and the bogs do not seem to attract large-scale depositions. As Stevans and Chapman (2020:19) argue from a summary of the UK examples, most of the Neolithic and early to middle Bronze Age bog bodies, concentrated in the fenlands, seem to be formal burials. It is in the later Bronze Age and Iron Age that human interactions with the bog (construction, extraction and deposition) begin to alter that relationship. The many trackways, platforms, artefactual, animal and human deposits that form the focus of this book need to be contextualised in that shifting relationship with the mosses of northern Europe. At this stage, violent death and dismemberment increases but in line with cultural activity in other wetland (and some dryland) examples (a pattern also observed by Stevans and Chapman 2020: 19-20). Whether these communities were conquered or not, the violence seen in these barbarian tribes was further stoked and inflamed by the ruptures of conquest and resistance, rippling out from the Roman world. In areas such as Denmark and Germany this begins to take on a more massive, martial character, while in Britain, Scotland and Ireland the last few centuries BC and first few centuries $\mathrm{AD}$ mark some of the most intense periods of bog offerings and ritual killings, smaller in scale but rich in value, whatever their motivation. We cannot escape the sense of a time of crises that prompted extraordinary gestures, turning the classical authors' texts on their heads. These were not necessarily the innate bloodthirsty rites of a savage people but the responses of communities undergoing the rupturing dissolution of their own social systems and influenced by new concepts of violence wrought by armies on the move, if not actual conquest. Formal Roman era burials or interments in bogs are also known, particularly in the UK (Stevans and Chapman 2020).

We then see a period of quiet in the bogs, in depositional terms at least, before a resurgence of interest in both their metaphysical and practical usefulness. In medieval Christian psychogeography, the landscape of the bog, the moss and the mire begin to be reshaped to embody purgatory or portals to hell. The bodies found in this era may well be members of the 'dangerous dead' who were exiled from consecrated ground but had to be placed somewhere: revenants and restless priests, executed criminals, drownings, suicides, murders and the unbaptised. Most of these remains are clothed and often coffined, representing a formal interment (Stevans and Chapman 2020: 20), even if this is a non-normative locale. These pejorative associations heralded their demise; bogs became seen as an unproductive waste, justifying drainage, clearance and cultivation. By the seventeenth to the nineteenth century, this was not only technically possible but morally necessary. The dead from this era look marginal: accidents wrought upon those unfamiliar with its mercurial territory (hawkers and traders), risky crossings, unwise and illegal 
endeavours (particularly poaching), murders and suicides, in what had become a desolate and liminal spot. In Scotland and Ireland in particular, this era is marked also with victims of conflict and religious persecution (Cowie et al. 2011). Those that still lived in some harmony with the bog often found themselves vilified, castigated and cleared, to the profit of private landowners or more recently state bodies. The relative desertion of the boglands attracted nefarious and sometimes violent incidents but by this time, most raised bogs or mires had been under the spade or the machine for generations. They were disappearing (we now know) to our future jeopardy, but giving up their dead in the process.

Against this sketch of changing rhythms of inhabitation and deposition, we can situate our historiography of bog body interpretations. As those remains came back to light, the earliest records we have (see Chapter 2) convey a sense of both concern and awe at the 'marvel' of preservation: they were either saints or sinners. These post-medieval accounts are blended with more pragmatic folk history: lost local characters, executed criminals, persecuted non-conformists, murder or conflict victims. Archaeology played its part here in 'evidencing' the major thresholds or events that shaped national identity. The antiquarian Enlightenment 'reporting' of this phenomenon and scientific or forensic enquiry ran hand in hand with burgeoning Romanticism (such as Countess Moira's famine victim who was later interpretively transformed into part of a Druidic ritual). As classical education was increasingly mobilised in antiquarian histories, it was Arends (1824) in Germany who revitalised the use of Tacitus to portray bog bodies as a ragbag of cowards, deserters and degenerates, a model that was further mobilised in the Nazi period to very particular, prejudicial ends. Johanna Mestorf (1900), who first named the phenomenon, saw them as 'punishment' victims yet could not quite accommodate the evidence for women or children within this judicial theory. The number of staked or weighted down bog bodies led Martin (1924) to mobilise the 'Wiedergänger' theory of the restless or dangerous dead, an idea that Struve (1967) supported and that both von Haugwitx (1993) and Watkins (2013) have demonstrated has merit and relevance certainly to the post-medieval bog dead. The vast numbers of bog bodies for whom no discernible cause of death can be seen prompt us to ask how, in the past, did communities deal with a mysterious or troubling death? As Fontijn (2020) evokes in relation to objects, the bog, with all of its properties and powers, may simply have been thought of as the 'right place' to deal with difficult and dangerous things.

Van der Sanden (1996: 169; 2006) argues that Continental scholarship then began to pluralise interpretations, most notably in Dieck's thoughtful yet flawed and inflated scholarship. Jankuhn (1977) linked the notion of execution to religious practice - punishment had a sacred significance, for transgression could offend the gods - the Strafopferthese. It was in Denmark that this notion of sacrality and sacrifice was then popularised by Thorvildsen (1952), before Glob's ([1969] 1971) thesis on the bog bodies as fertility offerings to supernatural powers. We can see the legacy of this in much of the work on ritual killing by Stead et al. (1986), sacrificial theory by Taylor (2008) and Aldhouse-Green (2002, 2016), as votive offerings (in Bradley 
2017) or depositions (Fontijn 2020). Ravn (2010) reminds us that some were normal burials, Lund (2002) sees the bog bodies as outcasts and witches, while Fredengren and Löfqvist (2015) find evidence for marginal lives. In Ireland, Kelly (2013) sees the ruined bodies of failed kings in his bog bodies. Some of these remains can now tell us very specific stories of their lives that help narrow these possibilities but others remain a relative mystery; as Glyn Daniel asked back in 1952, stood over the body of Tolland Man: 'Is this the face of a criminal, is this face of a prisoner of war, or is the victim of some prehistoric murder?' (BBC 1954). It is a question we still find hard to answer, but building on van der Sanden's (1996) still masterly work, Fischer (2012), Asingh and Lynnerup (2007), Burmeister (2007, 2013), Joy (2009), Fredengren $(2015,2018)$ and Chapman $(2015)$ have brought richer, contextual approaches to the study that integrate osteobiography with wider landscape context and depositional practice; that is the methodological approach followed here.

A neo-pragmatic and anti-ritual resurgence is represented in the UK at least, by Connolly (1985), Briggs (1995) and Hutton (2004a, 2004b) who resented what they saw as an unfounded 'sanctification' of accidental death or murder through the trope of sacrifice. The archival work presented here, building on the catalogues of Briggs, Turner and van der Sanden certainly provides further historic evidence for accident, murder and suicide on the bog, but as noted above, this tends to leave a particular forensic trace (fully clothed, with possessions) that fails to fit most of the Iron Age and Roman bog bodies. The chapter has shown that these clearer-cut cases can be vividly contrasted with the staging and execution of violence that has a more ritualised and performative dimension. It has resituated the scale and character of this violence within analogous evidence for Iron Age conflict and depositional practice to show that the bog bodies form part of a much wider cultural phenomenon of bellicosity and violence as an important trope of power. The next chapter will consider how this may have been transformed by the Roman world.

The following list summarises the multiple theories relating to bog bodies across all periods:

(1) Accidental death:

(a) during everyday tasks or crossing of the bog;

(b) misadventure (e.g. drowning while inebriated or inadvisable travel);

(c) bog bursts;

(d) escaping/fleeing conflict.

(2) Suicide:

(a) individual, lone suicide;

(b) assisted suicide, mercy killing or euthanasia.

(3) Murder:

(a) pathological killing;

(b) gendercide (including targeting of marginal or vulnerable groups) and infanticide;

(c) manslaughter (violent mugging or crime of passion/heat of the moment). 
(4) Execution:

(a) of criminals;

(b) of enemies (inter-/intra-tribal, ethnic or colonial);

(c) of captives (high- and low-status hostages);

(d) of those suspected of supernatural malignancy ('witches');

(e) of those feared due to 'contamination' (disease, infection, etc.);

(f) of 'failed leaders/kings';

(g) of those persecuted for faith, ethnicity, sexual orientation, etc.

(5) Dealing with the dead:

(a) formal burial (perpetual and/or expedient);

(b) formal burial (temporary, creating a useful corpse or corporeal elements, as ancestral mnemonic or enemy trophy);

(c) use of the bog for mysterious, troubling deaths (excised from normative rites or places of burial);

(d) use of the bog to control death of a powerful figure (e.g. witch, king) or suspected revenant.

(6) Sacrifice:

(a) scapegoating (symbolic excision of violence, guilt or crimes);

(b) augury and divination;

(c) appeal, exchange or repayment of supernatural debt;

(d) harnessing of transcendent vitality/fertility rites.

(7) Self-sacrifice/self-offering (possibly as a 'good' way to die?):

(a) gift of life;

(b) emissary;

(c) becoming sacred (ancestor, supernatural agent or entering the divine).

These categories are not mutually exclusive: for example, accidental death may shade into suicide; suicide itself may not be 'voluntary' but brought about through terror or social exile; a feared enemy captive may be used for violent divination; persecution on the grounds of sexual orientation could be counted as gendercide; and self-sacrifice might be classed as a kind of assisted suicide or euthanasia. Nonetheless, we can see at a glance that Glob himself was right to warn us - no one explanation will suffice.

Where does this leave us in relation to the Iron Age dead? Van der Sanden (1996: 174) supports the idea that 'many of the isolated bog bodies are to be interpreted as human sacrifices ... [in] watery environments [where] ... people sought contact with the supernatural world'. This interpretation is upheld in both Williams (2003) and Giles (2009) with the proviso that this could include the selfoffering of an individual, sometimes out of duty or skill but also perhaps a desire to bring life to a close, altering both the balance of power, intent and post-mortem fate of such a sacrifice. This may have been a strategy to become a powerful supernatural being, mediating with the sacred or entering the divine. Reflecting on the phenomenon of his composite Hebridean 'mummies', Parker Pearson (2016: 15) 
thus encourages us to rethink this era as a time when the world was populated by 'a complex constellation of beings, both alive and dead'. It was the medium of the bog itself that allowed people to manipulate time, or at least the effects of time, and as we know this quality has awed or intimidated every community that has seen its effects. Yet this slowing of time causes Taylor (2008: 145) concern: he rejects the notion that the bog was a threshold or portal, arguing instead that its cold cessation of decay was meant to 'vex the ghost and prevent the progress of the soul. The notion of the bog as a kind of purgatory might be eschatologically anachronistic for the Iron Age, given the temporary immersion of both butter and bodies which reemerged, changed into something 'rich and strange' (to paraphrase Shakespeare's account of the transformative effect of the sea upon a body, The Tempest Act 1, Scene 2). It also sees the physical world as one of divided realms with hard-drawn boundaries that were simultaneously material and supernatural, instead of a world where the spiritual resided and was immanent in such places. The bog was one (but only one) of the powerful places where Iron Age people could deal with the 'end' of things redolent with life force and reproductive power; I believe this included those marked by or for death (for many different reasons) who required particular care. As we have seen, this was a violent world in which lives were taken for many reasons. The boundary we may draw here between a 'pragmatic' and a 'ritual' killing may not be relevant: in someone's eyes, these were necessary deaths. Such life forces, such vitalities, were potentially dangerous and destabilising, yet potent. It was here in the bog that the cycle of becoming and dying could be manipulated, violently where required, and the final value of the bog bodies could be achieved, by entering this 'thin' place ... a place of hierophany. 